\title{
Bispecific, T-Cell-Recruiting Antibodies in B-Cell Malignancies
}

\author{
Margaux Lejeune ${ }^{1}$, Murat Cem Köse', Elodie Duray ${ }^{1}$, Hermann Einsele ${ }^{3}$, Yves Beguin ${ }^{1,2}$ \\ and Jo Caers ${ }^{1,2 *}$ \\ ${ }^{1}$ Laboratory of Hematology, GIGA 13, University of Liège, Liège, Belgium, ${ }^{2}$ Department of Hematology, CHU de Liège, Liège, \\ Belgium, ${ }^{3}$ Department of Internal Medicine II, University of Würzburg, Würzburg, Germany
}

\section{OPEN ACCESS}

Edited by:

Christian Klein,

Roche Innovation Center Zurich,

Switzerland

Reviewed by:

Diego Ellerman,

Genentech, Inc., United States

Luis Alvarez-Vallina,

Aarhus University, Denmark

*Correspondence:

Jo Caers

jo.caers@chu.ulg.ac.be

Specialty section:

This article was submitted to Cancer Immunity and Immunotherapy,

a section of the journal

Frontiers in Immunology

Received: 13 December 2019

Accepted: 03 April 2020

Published: 07 May 2020

Citation:

Lejeune M, Köse MC, Duray E, Einsele $H$, Beguin $Y$ and Caers $J$ (2020) Bispecific, T-Cell-Recruiting Antibodies in B-Cell Malignancies.

Front. Immunol. 11:762. doi: 10.3389/fimmu.2020.00762
Bispecific antibodies (BsAbs) are designed to recognize and bind to two different antigens or epitopes. In the last few decades, BsAbs have been developed within the context of cancer therapies and in particular for the treatment of hematologic B-cell malignancies. To date, more than one hundred different BsAb formats exist, including bispecific T-cell engagers (BiTEs), and new constructs are constantly emerging. Advances in protein engineering have enabled the creation of BsAbs with specific mechanisms of action and clinical applications. Moreover, a better understanding of resistance and evasion mechanisms, as well as advances in the protein engineering and in immunology, will help generating a greater variety of BsAbs to treat various cancer types. This review focuses on T-cell-engaging BsAbs and more precisely on the various BsAb formats currently being studied in the context of B-cell malignancies, on ongoing clinical trials and on the clinical concerns to be taken into account in the development of new BsAbs.

Keywords: bispecific antibodies, leukemia, lymphoma, myeloma, bispecific T-cell engager, BiTE, clinical development, concerns

\section{INTRODUCTION}

The idea of bispecific antibodies (BsAbs) was initially launched in the early 1960s and the first examples were constructed in 1985 (1). Ten years later, a BsAb (anti-CD19 $\times$ anti-CD3) was studied in a clinical trial for the treatment of non-Hodgkin's lymphoma (NHL) (2) and it took until 2009 for the approval of catumaxomab (anti-epCAM $\times$ anti-CD3) for the treatment of patients with malignant ascites (3). Advances in protein engineering enable the creation of BsAbs with specific mechanisms of action and clinical applications (4). Although catumaxomab was withdrawn from the market in 2017 for commercial reasons, the excellent clinical results of the bispecific T-cell engager (BiTE), blinatumomab (anti-CD19 $\times$ anti-CD3) (5), have renewed the interest and investment in BsAb development.

\section{BISPECIFIC ANTIBODIES}

Bispecific antibodies are designed to bind to two different antigens (Ag) or epitopes. These Ags can be present on the same cell, thereby improving the selectivity and binding kinetics of these antibody (Ab) formats. Most BsAbs are developed to bind different targets on different cells, which expand their potential applications. In immunotherapy, they are used to improve tumor cell eradication by bringing cytotoxic cells [T-cells or natural killer (NK)-cells] directly in contact with tumor cells. Given their potential economic value, the pharma industry has taken over their biotechnical 
development resulting in more than 100 different formats that have been designed (6). This review tries to focus on different T-cell recruiting formats that have been developed in the treatment of B-cell malignancies.

Effector cell-engaging BsAbs are generally made up of an effector cell-binding domain linked to a tumor Ag-binding fragment. The final format can be made of various known $\mathrm{Ab}$ fragments such as single-chain variable fragment $(\mathrm{scFv})$, heavy chain variable domain $(\mathrm{VH})$, light chain variable domain $(\mathrm{VL})$, variable region of a heavy chain of a heavy chain only $\mathrm{Ab}(\mathrm{VHH})$, diabody, etc.; or resemble the general architecture of immunoglobulins (Ig). Such fragments provide advantages and disadvantages according to their specific characteristics and properties. Therefore, selection of $\mathrm{Ab}$ fragments require careful evaluation, in order to create the most suitable BsAbs for the desired applications $(4,7)$. One single format is probably not suitable for all applications and BsAbs are generated according to desired characteristics. They differ in terms of size, valency, flexibility, distribution of their pharmacological properties, etc. The two most common forms of BsAbs are the IgG-based and Ab-fragment based formats. IgG-Based BsAb contain an Fc region that helps the stability of the BsAb and the production and purification procedures. Some of the formats of BsAbs currently used for hematological cancers are described in Tables 1, 2 and these various formats are shown in Figure 1.

\section{Bispecific Antibodies IgG-Like}

The Fc domain of an Ig facilitates BsAb purification, improves solubility and stability, extends their in vivo half-life (8) and activates several immune cells. When its effector functions are maintained, this $\mathrm{Fc}$ region will induce $\mathrm{Ab}$-dependent cellmediated cytotoxicity (ADCC) by recruiting NK-cells and/or macrophages and complement-dependent cytotoxicity (CDC) by binding the complement $(4,8)$.

Preferably, CD3-targeting BsAbs require the complete suppression of the Fc-mediated effector functions in order to maximize therapeutic efficacy and to minimize off-target toxicity because binding of $\mathrm{Fc}$ to $\mathrm{Fc}$ gamma receptor $(\mathrm{Fc} \gamma \mathrm{R})$ leads to activation of immune effector cells. In reality, the majority of the CD3-targeting BsAbs, currently in clinical practice, have $\mathrm{Fc}$ domains with reduced binding activity to $\mathrm{Fc} \gamma \mathrm{R}$ or are BsAb fragments intentionally without the Fc region (9).

However, IgG-like BsAbs composed of two different heavy chains and two different light chains are difficult to produce. The heavy chains of the Bsab can form homodimers (described as heavy chain-pairing problem) and also the light chains can pair to the incorrect heavy chains (light chain-pairing problem). Different solutions have been proposed to avoid these undesired mispairs and some of them are integrated in Table 1. A major progress in this field was the development of the "knobs-into-holes" ( $\mathrm{KiH})$ strategy that consisted of introducing large amino acid side chains into the $\mathrm{CH} 3$ domain of one heavy chain that fit into an appropriately designed cavity in the $\mathrm{CH} 3$ domain of the other heavy chain (10).

\section{Bispecific Antibodies Without Fc Region}

BsAbs lacking an Fc region can be produced by linking two different single-chain antibodies with a linker. Their Ag-binding part contain only the variable regions of the heavy and light chains connected to each other by a linker (Table 2). They are smaller than the bispecific molecules with an Fc region, and this reduced size results with increased tissue penetration, but also fast renal elimination resulting in a short plasma half-life. This reduced circulation time requires more frequent administrations or continued infusion $(11,12)$. The half-life can be extended using different engineering technologies, such as coupling to inert polymers (polyethylene glycol) (13) adding an Fc part (14), attaching an albumin-binding part (15) or even immunoglobulin-binding domains (16). Companies are currently introducing these half-life extended BsAb in order to limit the administration frequency and improve patients' comfort. Prospective clinical studies will investigate the efficacy and toxicity of these conjugated BsAbs and allow a comparison with the original BsAbs (e.g., AM701, an anti CD3 × BCMA BiTE) is a half-life extended version of AMG420 that showed promising results in the first phase I trial).

\section{RECRUITMENT OF EFFECTOR CELLS}

\section{Main Ag for Targeting T-Cells: CD3}

$\mathrm{BsAb}$ constructs guide immune effector cells to tumor cells by cell-specific receptors such as CD3 on T-cells or CD16 on NKcells. Currently, approximately half of the evaluated BsAbs by clinical trials are BsAbs that recruit T-cells (17). Their mechanism of action is based on the activation of T-cells by binding CD $3 \varepsilon$ in the T-cell receptor (TCR) complex irrespective of major histocompatibility complex (MHC) restriction or TCR epitope specificity. Although required for their anti-cancer activity, the binding to the antigen may lead to an excessive immune reaction with activation of bystander immune cells and non-immune cells that finally results in a cytokine release syndrome (CRS).

Most T-cell engaging BsAbs aim to bind CD $3 \varepsilon$ to guide T-cells to the target cells. An alternative Ag, CD5, has been previously explored (18) but the observed responses were inferior to those obtained with CD3e-binding BsAbs. Unfortunately, CD3 will recruit different types of T-lymphocytes (including immunesuppressive ones) that can limit their efficacy. For example, Duell et al. (19) showed that blinatumomab also activates regulatory T-cells (Tregs), who inhibit cytotoxic T-cell proliferation, thereby preventing tumor cell destruction. As a result, usage of NK-cells instead of T-cells draw attention in clinical development (see Table 3) (17).

CD3-based BsAbs targeting T-cells also demonstrated other disadvantages, such as (1) potentially high toxicity, particularly for targets with wide tissue expression; (2) partial tumor destruction and the development of resistance to treatment due Ag escape (8) and rapid and powerful activation of a large pool of T lymphocytes that is no longer counterbalanced by TCR regulation $(20,21)$. The interest in this type of BsAbs renewed after the first clinical results obtained with blinatumomab (see section "BiTE anti-CD19 - CD3") (22). Impressive responses 
TABLE 1 | Ab formats used for hematological cancers: Bispecific antibodies IgG-like.

\begin{tabular}{|c|c|c|c|c|c|c|c|c|c|}
\hline \multirow[t]{2}{*}{ Name/Platform } & \multirow[t]{2}{*}{ Firm } & \multirow[t]{2}{*}{ Characteristics } & \multicolumn{2}{|c|}{ Heavy chain engineering } & \multirow{2}{*}{$\begin{array}{l}\text { Light chain } \\
\text { engineering }\end{array}$} & \multirow[t]{2}{*}{ Fc domain } & \multirow[t]{2}{*}{ Production } & \multirow[t]{2}{*}{ Remarks } & \multirow[t]{2}{*}{ References } \\
\hline & & & $\begin{array}{l}\text { "Knob-in-hole" } \\
\text { technology }\end{array}$ & Other strategies & & & & & \\
\hline $\begin{array}{l}\text { BsAb armed } \\
\text { activated } \\
\text { T-cells (BAT) }\end{array}$ & $\begin{array}{l}\text { Mostely } \\
\text { academic }\end{array}$ & $\begin{array}{l}\text { Combination of an } \\
\text { mAb targeting the } \\
\text { tumor Ag with an mAb } \\
\text { targeting the effector } \\
\text { cells }\end{array}$ & No & No & No & Functional Fc & $\begin{array}{l}\text { Chemical } \\
\text { heteroconjugation of } 2 \\
\text { mAbs }\end{array}$ & $\begin{array}{l}\text { Combined with ex vivo } \\
\text { activated T-cells }\end{array}$ & 161 \\
\hline CrossMab & Roche & $\begin{array}{l}\text { Exchange of either the } \\
\text { constant domain, } \\
\text { variable domains or the } \\
\text { whole Fab fragment }\end{array}$ & Yes & Electrostatic steering & $\begin{array}{l}\text { Crossover of an } \\
\text { existing fragment } \\
\text { without the need for } \\
\text { the identification of } \\
\text { common light chains }\end{array}$ & $\begin{array}{l}\text { Fc part without effector } \\
\text { function }\end{array}$ & $\begin{array}{l}\text { Almost natural, } \\
\text { full-sized humanized } \\
\text { lgG1 antibody }\end{array}$ & $\begin{array}{l}\text { Not immunogenic, also } \\
\text { applied to } 2+1 \text { and } \\
2+2 \text { formats }\end{array}$ & 162,163 \\
\hline Veloci-Bi & Regeneron & $\begin{array}{l}\text { Common light chain } \\
\text { approach combined } \\
\text { with mutation of } \\
\text { protein A binding site } \\
\text { for improved } \\
\text { purification }\end{array}$ & No & $\begin{array}{l}\text { Selection of correct } \\
\text { heterodimers by } \\
\text { Protein A affinity } \\
\text { chromatography using } \\
\text { a new protein A resin }\end{array}$ & $\begin{array}{l}\text { Use of heavy chains } \\
\text { that employ identical } \\
\text { light chain }\end{array}$ & $\begin{array}{l}\text { Fc part without effector } \\
\text { function }\end{array}$ & $\begin{array}{l}\text { Recombinant } \\
\text { production, purification } \\
\text { enables identification } \\
\text { of correct } \\
\text { heterodimers }\end{array}$ & Not immunogenic & 164 \\
\hline SEEDbodies & & $\begin{array}{l}\text { Specific pairing } \\
\text { through the design of } \\
\text { alternating segments } \\
\text { from human IgA and } \\
\operatorname{lgG}\end{array}$ & No & $\begin{array}{l}\text { Strand-exchange } \\
\text { engineered domain: } \\
\text { interdigitating } \beta \text {-strand } \\
\text { segments of human } \\
\text { lgG and IgA } C_{H} 3 \\
\text { domains }\end{array}$ & $\begin{array}{l}\text { Additional engineering } \\
\text { for correct } \\
\text { heavy-to-light chain } \\
\text { pairing }\end{array}$ & $\begin{array}{l}\text { Fc part without effector } \\
\text { function }\end{array}$ & $\begin{array}{l}\text { Recombinant } \\
\text { production }\end{array}$ & $\begin{array}{l}\text { SEEDbodies assure } \\
\text { correct Heavy chain } \\
\text { pairing, but additional } \\
\text { engineering of light } \\
\text { chains can be } \\
\text { necessary }\end{array}$ & 165 \\
\hline Biclonics & Merus & $\begin{array}{l}\text { Charge pairs in the } \\
\mathrm{CH} 3 \text { that favor } \\
\text { heterodimerization }\end{array}$ & No & $\begin{array}{l}\text { Introduction of } \\
\text { charged residues at } \\
\text { different positions } \\
\text { within the Fc part }\end{array}$ & $\begin{array}{l}\text { Fab fragment } \\
\text { consisting of common } \\
\text { light chain fragments }\end{array}$ & $\begin{array}{l}\text { Fc part without effector } \\
\text { function }\end{array}$ & $\begin{array}{l}\text { VH genes cloned in the } \\
\text { backbone lgG1; } \\
\text { Recombinant } \\
\text { production of full IgG }\end{array}$ & 1 & 166,167 \\
\hline XmAb & Xencor & $\begin{array}{l}\text { Typically, scFv fused to } \\
\text { one Fc instead of Fab } \\
\text { fragment to enable } \\
\text { bispecificity }\end{array}$ & Yes & $\begin{array}{l}\text { Set of minor and } \\
\text { precise changes to the } \\
\text { Fc region leading } \\
\text { enhanced } \\
\text { heterodimerization } \\
\text { Improved purification } \\
\text { procedure }\end{array}$ & $\begin{array}{l}\text { Different formats exist: } \\
\text { Fab or ScFV }\end{array}$ & $\begin{array}{l}\text { Fc part without effector } \\
\text { function }\end{array}$ & $\begin{array}{l}\text { Recombinant } \\
\text { production and } \\
\text { purfifiction by I protein } \\
\text { A affinity } \\
\text { chromatography }\end{array}$ & $\begin{array}{l}\text { Full-sized humanized } \\
\text { lgG1 Ab, nearly } \\
\text { identical to natural Ab } \\
\text { (similar structure and } \\
\text { sequence) }\end{array}$ & 168 \\
\hline Duobody & Genmab & $\begin{array}{l}\text { Controlled Fab-arm } \\
\text { exchange (cFAE) from } \\
\text { two parent } \\
\text { homodimeric } \\
\text { antibodies }\end{array}$ & Yes & Fc silent mutations & $\begin{array}{l}\text { Separate expression } \\
\text { and purification of the } \\
2 \text { component } \\
\text { antibodies followed by } \\
\text { assembly into BslgG }\end{array}$ & $\begin{array}{l}\text { Fc activity can be } \\
\text { retained or silenced } \\
\text { depending on the } \\
\text { characteristics desired }\end{array}$ & $\begin{array}{l}\text { Almost natural, } \\
\text { full-sized humanized } \\
\text { lgG1 antibody }\end{array}$ & $\begin{array}{l}\text { Full-sized humanized } \\
\text { IgG1 Ab, minimal } \\
\text { modifications to the } \\
\text { native Ab structure }\end{array}$ & 169 \\
\hline $\begin{array}{l}\text { TriFAb } \\
\text { (Trifunctional } \\
\text { Ab) }\end{array}$ & TRION & $\begin{array}{l}\text { Produced from two } \\
\text { half antibodies from } \\
\text { parental mouse lgG2a } \\
\text { and rat lgG2b isotypes }\end{array}$ & No & ' & $\begin{array}{l}\text { Species-restricted } \\
\text { heavy/light chain } \\
\text { pairing }\end{array}$ & $\begin{array}{l}\text { Fc part with effector } \\
\text { function }\end{array}$ & $\begin{array}{l}\text { Produced using the } \\
\text { quadroma technology } \\
\text { and captured by } \\
\text { protein A affinity } \\
\text { chromatography }\end{array}$ & $\begin{array}{l}\text { Trifunctional } \geq \text { Highly } \\
\text { immunogenic and } \\
\text { toxic (CRS) }\end{array}$ & 170 \\
\hline
\end{tabular}


TABLE 2 | Ab Formats used for hematological cancers: Bispecific antibodies with single chain formats.

\begin{tabular}{|c|c|c|c|c|c|c|c|}
\hline & Characteristics & Molecular Weigth & Half life & Linker & Administration & Remarks & References \\
\hline BiTE & $\begin{array}{l}2 \text { scFv fragments, } \\
\text { connected by } \\
\text { flexible linker } \\
\text { peptides }\end{array}$ & $\sim 55 \mathrm{kDa}$ & $2 \mathrm{~h}$ & $\begin{array}{l}\text { 15-amino acid } \\
\text { (G4S1)3 } \\
\text { (single-letter amino } \\
\text { acid code) linker }\end{array}$ & Continuous infusion & $\begin{array}{l}\text { Rely exclusively on } \\
\text { effector-tumor } \\
\text { synapse formation }\end{array}$ & 171 \\
\hline BiKE & $\begin{array}{l}\text { BiKEs: } 2 \text { scFv } \\
\text { fragments, } \\
\text { connected by } \\
\text { flexible linker } \\
\text { peptides are similar } \\
\text { in design to BiTEs } \\
\text { but they target } \\
\text { CD16 on NK-cells }\end{array}$ & $58-60$ kDa & ND & $\begin{array}{l}\text { 20-amino acid } \\
\text { segment of human } \\
\text { muscle aldolase }\end{array}$ & ND & $\begin{array}{l}\text { Not immunogenic, } \\
\text { further expansion of } \\
\text { NK-cells (TriKE) }\end{array}$ & 172,173 \\
\hline TriKE & $\begin{array}{l}\text { TriKEs consist of a } \\
\text { BiKE into which } \\
\text { IL-15 was } \\
\text { subsequently } \\
\text { sandwiched }\end{array}$ & $\sim 96 \mathrm{kDa}$ & ND & $\begin{array}{l}\text { Human IL-15 with } \\
\text { N72D substitution, } \\
\text { flanked by two } \\
\text { flanking sequence }\end{array}$ & ND & $\begin{array}{l}\text { Mutated form of } \\
\text { IL-15 expands } \\
\text { NK-cells }\end{array}$ & 173 \\
\hline Diabodies & $\begin{array}{l}\text { A single-chain } \\
\text { format based on } 2 \\
\text { peptides, each one } \\
\text { contains a heavy } \\
\text { chain variable } \\
\text { region }(\mathrm{VH}) \text { for an } \\
\text { Ag recognition site } \\
\text { paired with a light } \\
\text { chain variable } \\
\text { region }(\mathrm{VL}) \text { of a } \\
\text { second } \mathrm{Ag} \\
\text { recognition site }\end{array}$ & $58 \mathrm{KDa}$ & $2 \mathrm{~h}$ & $\begin{array}{l}15 \text { amino acids } \\
\text { with sequence } \\
\text { GGGGSGGRASGGGGS }\end{array}$ & $\begin{array}{l}\text { Frequent injections } \\
\text { or infusions }\end{array}$ & $\begin{array}{l}\text { Variants of } \\
\text { diabodies consist } \\
\text { of dual-affinity } \\
\text { retargeting } \\
\text { molecules (DART) } \\
\text { or tetravalent } \\
\text { constructs that } \\
\text { combine two } \\
\text { diabodies (TandAb) }\end{array}$ & 174 \\
\hline
\end{tabular}

A

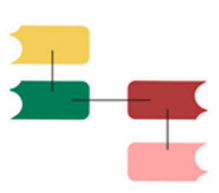

B

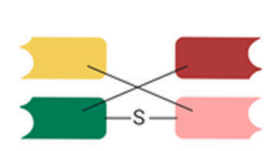

C

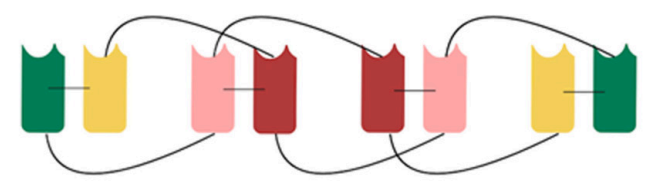

D

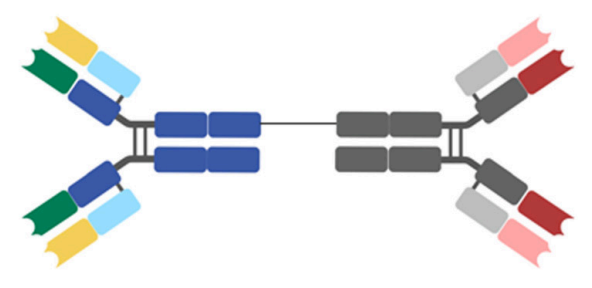

E

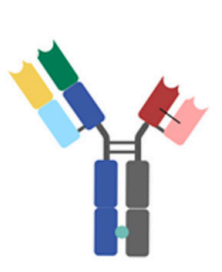

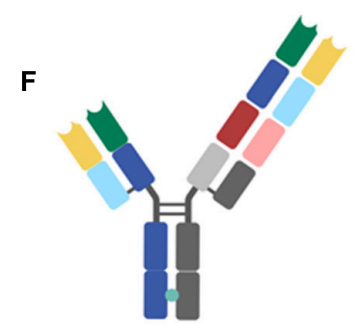

G

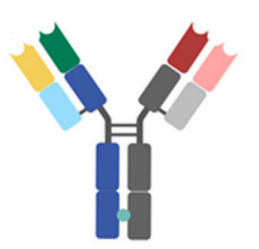

H

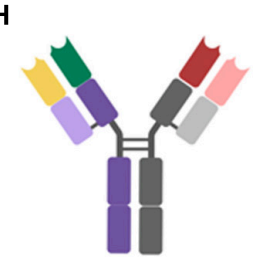

FIGURE 1 | BsAb formats studied for hematological B-cell malignancies (A), BiTE (Tandem scFvs); (B) DART; (C) TandAb (Tandem diabodies); (D) BAT; (E) TDB: Xmab (scFv-Fab IgG); (F) TCB: CrossMAb; (G) TDB: DuoBody; (H) TriFAb (Rat-mouse hybrid IgG). The different antibody domains are as follows: green, variable region of heavy chain 1 (VH 1); red, variable region of heavy chain 2 (VH 2); yellow, variable region of light chain 1 (VL 1); pink, variable region of light chain 2 (VL 2); light purple, constant region of light rat chain; dark purple, heavy chain of immunoglobulin G2b (lgG2b); light blue and light gray, constant regions of light mouse chain; dark blue and dark gray, heavy chains of mouse lgG2b; turquoise circles, Knob-in-Hole (KiH) BiTE, bispecific T-cell engager; DART, dual-affinity re-targeting; Fab, Fab region; S, disulfure; scFv, single-chain variable fragment; TandAb, tandem diabody; TDB, T-cell-dependent bispecific antibody; TriFAb, trifunctional antibody, triomab. 
TABLE 3 | Clinical development of BsAbs (selected trials).

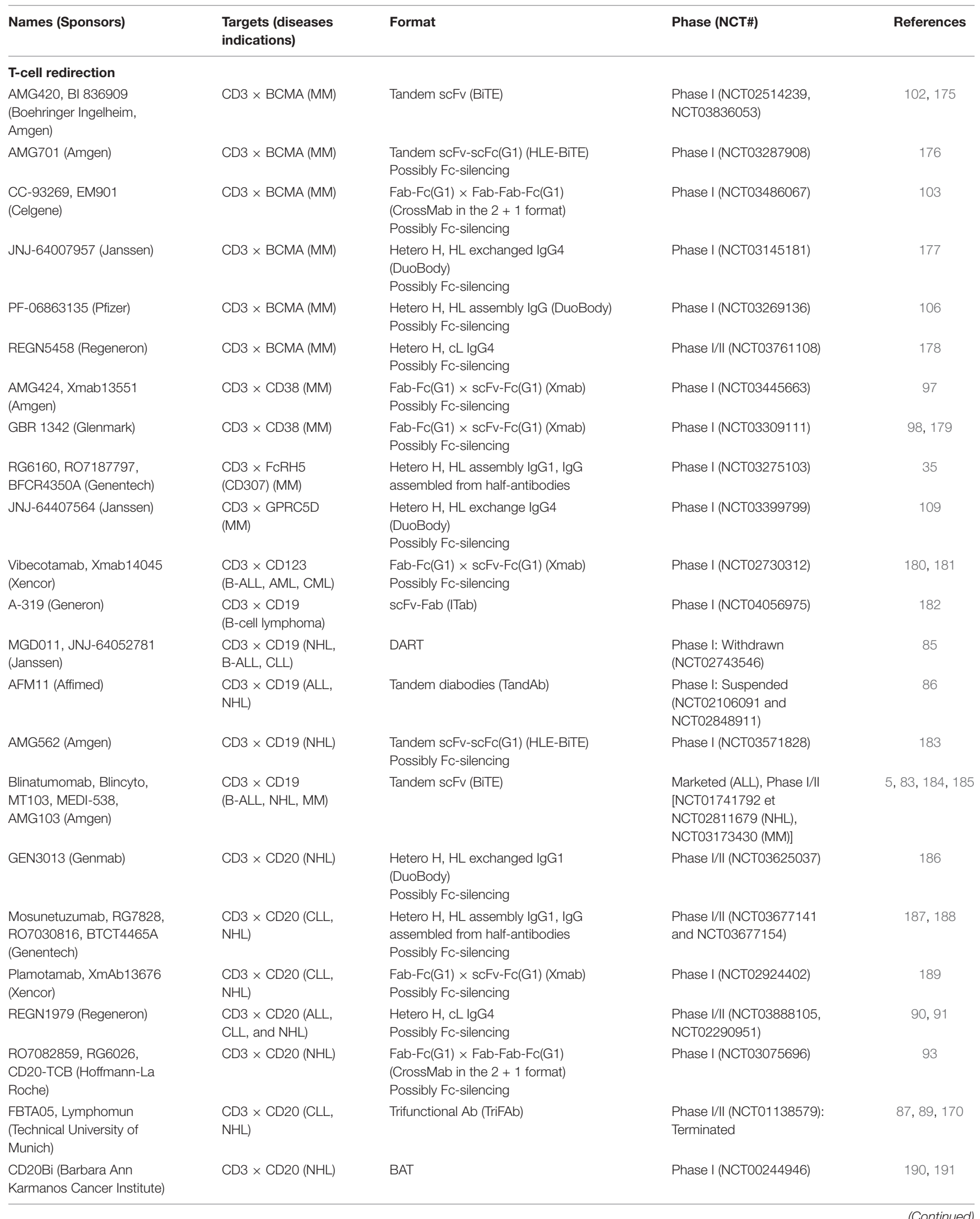


TABLE 3 | Continued

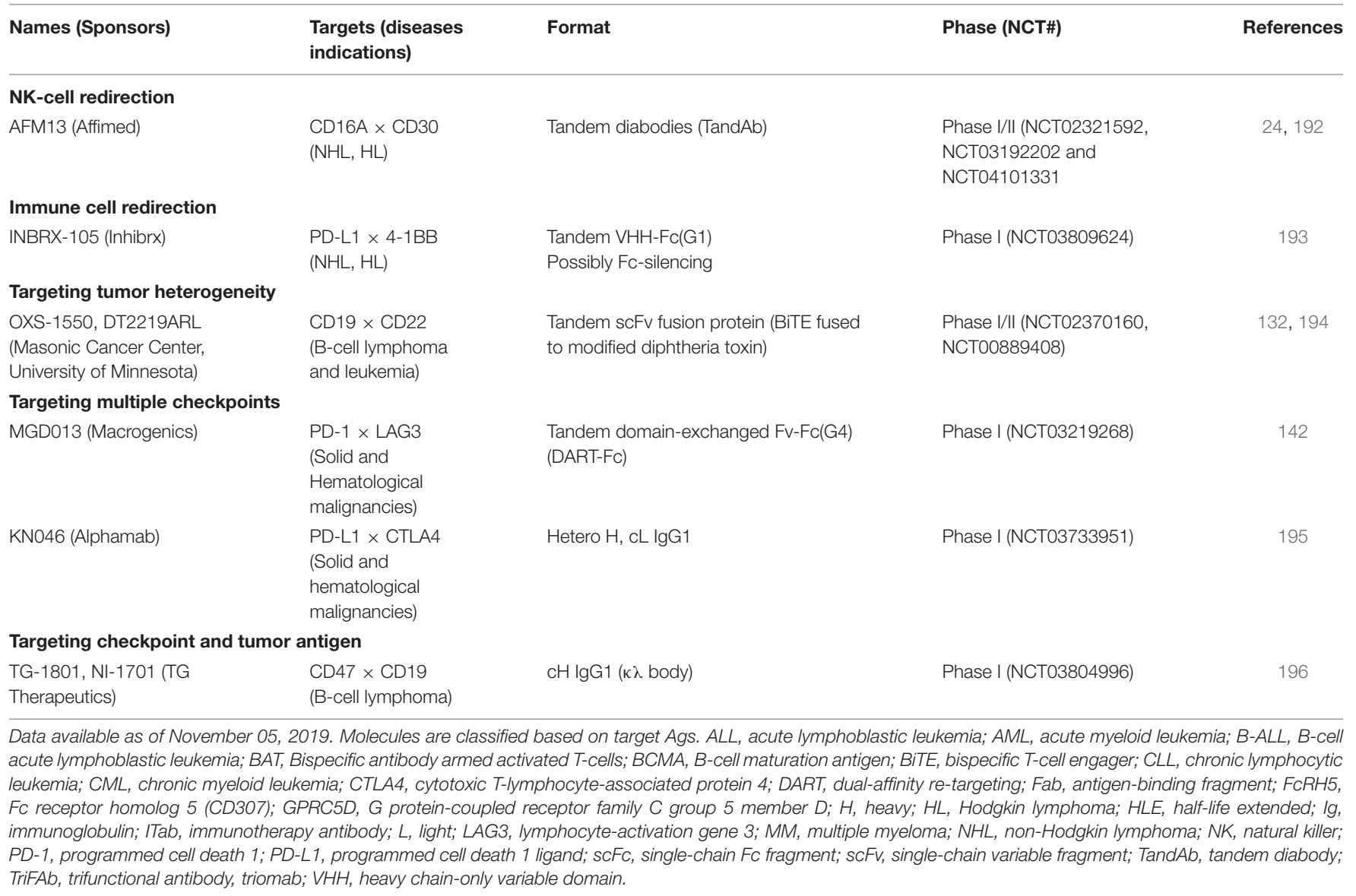

were observed at very low doses in patients with NHL who received blinatumomab via a continuous intravenous infusion to reach the desired minimum concentrations (22). In addition, an exceptional complete response rate of $43 \%$ was reported in the first studies on relapsed/refractory (r/r) acute lymphoblastic leukemia (ALL) (23).

\section{Main Ag for Targeting NK-Cells: CD16A}

An alternative to T-cell usage consists in activating and directing NK-cells to malignant cells. Compared to T-cells, NK-cells are not subjected to HLA restriction. In addition, NK-cell therapies may be better tolerated by patients than their T-cell counterparts (24). Several receptors capable of activating the cytotoxic function of NK-cells have already been described, notably CD16, NKp30, NKp46, NKG2D and DNAX Accessory Molecule-1 (DNAM1) $(25,26)$. Contrary to other activating receptors present in human NK-cells, CD16 can strongly trigger activation without co-stimulatory receptors. There are two isoforms of CD16 in humans, CD16A and CD16B, having a low affinity receptor for IgG Fc domain. CD16A is expressed in NK-cells, macrophages and placental trophoblasts, whereas $\mathrm{CD} 16 \mathrm{~B}$ is expressed in neutrophils. Only the CD16A isoform is capable of triggering both IL-2 secretion and tumor cell destruction (27).

Despite its advantages, CD16 is often cleaved on the surface of NK-cells by a disintegrin and metalloptroteinase-17 (ADAM17) which likely results in a decrease in the activities mediated by this receptor (28). To address this concern, combining a BsAb and ADAM17 inhibitor was evaluated and showed improved therapeutic efficacy (29). An alternative solution is targeting other receptors on the NK-cells, alone or in parallel to CD16. Recently, the group of E Vivier showed the increased cytotoxic effect of targeting two activating receptors, NKp46 and CD16, on NK-cells (30).

Lastly, in addition to directing the cytotoxicity of the NK-cells, improvements were made to their survival and proliferation. IL-15 was incorporated into a Bispecific Killer cell Engager (BiKE) structure to create a Trispecific Killer cell Engager (TriKE) which was confirmed to have the capability to enhance NKcell cytotoxicity with improved survival and proliferation in vitro (31).

\section{BINDING TO TUMOR CELLS}

Various parameters will influence the effectiveness of the BsAbs activity. The major factors that determine whether an Ag is a good target include (1) tumor-specificity and absence on healthy tissues (32), (2) prevalence and level of expression on tumor cells (32), (3) potential expression on malignant precursor or stem cells (33), and (4) low levels of circulating, soluble forms. 
Moreover, the cytotoxic potential of BsAbs is affected by the target Ag size and the distance between the epitope and the target cell membrane $(34,35)$. For example, if the distance between the epitopes is large, inhibitory molecules can interfere with the formation of the synapse (35). To achieve optimal effector cell activation, the affinity of the monoclonal $\mathrm{Ab}$, the location of the target epitope in the antigen (Ag) and the Ag density on the surface of the target cells must be taken into account (10).

Furthermore, the low number of truly tumor-specific cell surface molecules limits the use of BsAbs in to cancers where the target Ag is highly overexpressed in malignant cells compared to healthy cells and when the related toxicity toward healthy cells is clinically tolerable (36). Most BsAbs in clinical development target well-known B-cell Ags, particularly the CD19, CD20, CD38, CD123, or B-Cell Maturation Ag (BCMA). These targets are generally also expressed by normal plasma cells and B-cells. Nevertheless, depletion of these cells can be tolerated without inducing serious clinical side effects (17). In addition, these targets are specific for hematopoietic lineage and are not expressed in other normal tissues, which helps to reduce offtumor activity and side effects.

\section{B-CELL MALIGNANCIES}

The B-cell subtypes and the various associated malignancies as well as the different Ags expressed in the B-cell lineage are shown in Figures 2, 3.

\section{Acute Lymphoblastic Leukemia}

Acute lymphoblastic leukemia (ALL) is a hematological malignancy induced by proliferation and accumulation of immature lymphoblasts in various tissues. It is seen in both pediatric and adult patients, showing a bimodal distribution (37). While young patients have a good prognosis, the outcome for adults can be dismal $(38,39)$. Its prognosis depends further of other factors, such as age, chromosomal abnormalities, genetic alterations and the implicated cell lineage. Although, ALL can be derived from NK-cell, T-cell and B-cell lineages, the majority of the disease is associated with B-cell precursors $(40,41)$. Chromosomal abnormalities play a critical role in development of ALL. The Philadelphia chromosome (Ph) or translocation $t(9 ; 22)$, is a critical anomaly that determine the characteristic of the disease, yielding poor prognosis $(42,43)$. Initially, patients are diagnosed based on the abundance of lymphoblasts ( $>20 \%$ ) in bone marrow or blood (44). Since ALL is associated with premature B-cells, B-cell specific differentiation markers; CD19, CD20, and CD22, are highly associated Ags that are used for diagnosing and targeting with immunotherapeutic agents $(40,45)$.

\section{Chronic Lymphocytic Leukemia}

Chronic lymphocytic leukemia (CLL) is a hematologic disorder defined by accumulation of monomorphic mature B-cells within blood, bone marrow, lymph nodes, and spleen (46). It is observed with a median age at diagnosis of 70 and male:female ratio of 1.5 (47).
Chronic lymphocytic leukemia progression is driven by various genetic abnormalities. Somatic mutations, such as TP53, BIRC3, NOTCH1, ATM, and SF3B1 disrupt pathways including DNA damage, cell cycle control, NOTCH signaling and mRNA processing (48-50). Deletion of chromosome 13 (loss of miR-15a and miR-16-1) and trisomy 12 are the most common chromosomal aberrations observed in CLL, triggering tumorigenesis. Secondary abnormalities are observed at the later stages of the disease, causing resistance to therapy. Essentially, the presence of mutations or deletions in the p53 gene and the mutation status of the immunoglobulin heavychain variable region gene $(\mathrm{IGH})$ are strong indicators of poor prognosis (51-54).

Chronic lymphocytic leukemia is well characterized by the expression of CD5 and CD23 along with B-cell markers CD19, CD20, together with high abundance of a single light chain ( $\kappa$ or $\lambda$ ), due to clonal B-cell amplification (46). The diagnosis is obtained by immunophenotyping and blood count of B-cells. If monoclonal B-cells are more than 5000 cells per $\mu \mathrm{L}$, the diagnosis of CLL is retained (55).

\section{Multiple Myeloma}

Multiple myeloma (MM) is an incurable malignancy, caused by monoclonal proliferation of non-functional plasma cells in the bone marrow (56). The median age at diagnosis is 69 years with median overall survival of 8.5 years for transplant-eligible patients (57). Although good response rates are observed with initial therapy, the disease relapses and no longer responds to therapy, causing poor prognosis (56).

Multiple myeloma is characterized by the secretion of monoclonal immunoglobulins or light chains (described as M-protein). Initially, it is a benign disorder where 5 to $10 \%$ can evolve into a symptomatic malignancy $(58,59)$. This progression is driven by a clonal evolution within malignant plasma cells. The genomic infrastructure of MM is highly heterogeneous. Although, the events leading to MM transformation are unclear, numerous genetic abnormalities contribute to disease progression. Disruption of regulation of cyclin $\mathrm{D}$ and $\operatorname{IgH}$ proteins, including translocations $t(11 ; 14)$ and $t(4 ; 14)$, are common chromosomal abnormalities observed in early stages, together with hyperdiploidy located in odd chromosomes $(60,61)$. During progression, as the disease advances, the genetic stability decreases. Additional aberrations, such as chromosomal loss/gains, somatic mutations (KRAS, NRAS, and TP53), hypermethylation and more translocations (MYC), trigger further oncogenic events $(62,63)$.

An initial diagnosis is assessed by monoclonal protein level, bone marrow biopsy, radiologic imaging and is based on the presence of symtoms (annotated by the acronym CRAB: hypercalcemia, renal failure, anemia and bone lesion) $(64,65)$. Furthermore, the disease stage can be obtained by International Staging System (ISS) (66), revised on 2015 with additional genetic risk factors (67). Although there is no specific gene marker for MM, Ags such as CD38, BCMA, and CS1/SLAMF7, are currently targeted by immunotherapeutic strategies (68). 


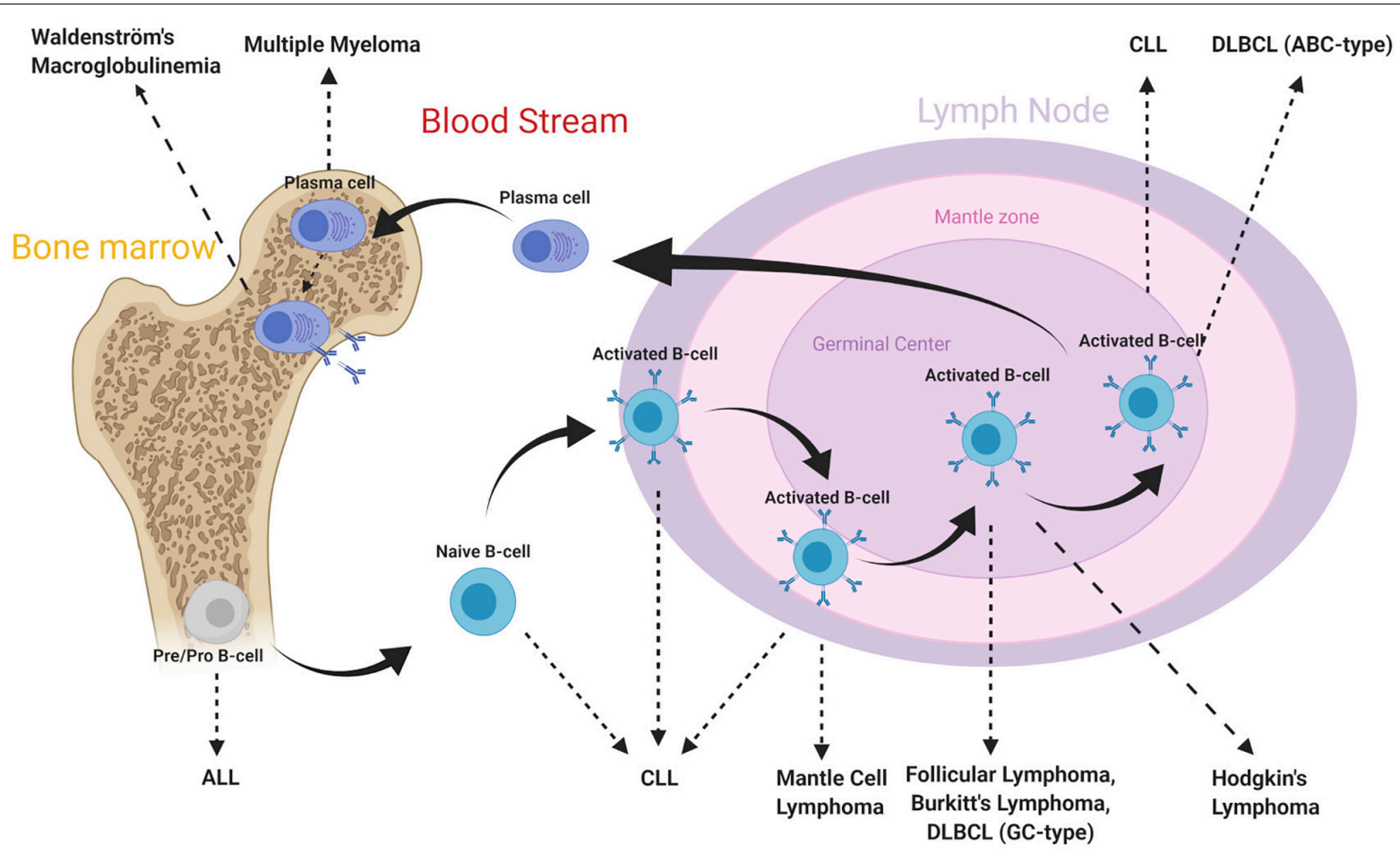

FIGURE 2 | B-cell subtypes and associated malignancies. From Hematopoietic stem cell differentiation into myeloid and lymphoid lineages. After Ag-binding, B-lymphocytes further mature in lymphoid tissues where they undergo various morphological, genetic, and chromosomal alterations. As a consequence, various cell surface Ags reside on cell membrane along maturation process. Disruptions in these mechanisms may lead to the development of malignancies. The B-cell malignancies are divided into subgroups based on location, subtype and activation state of B-cells. This figure is adapted from (70, 159).

\section{Non-Hodgkin Lymphomas}

Non-Hodgkin lymphomas are B-cell malignancies that are primarily located in lymph nodes. The disease progression is driven by precursor lymphocytes, where $85 \%$ of the cases emerge from B-cell precursors (69). The 5-year survival rates vary highly, from $30 \%$ to $86 \%$, among the subtypes of NHL (70). These subtypes are mainly categorized into two groups. Aggressive lymphomas are rapidly evolving entities with a high tumor cell proliferation rates, but potentially curable when responding to high-dose chemotherapy. In contrast, indolent subtypes represent low grade lymphomas and are incurable (71).

Specific translocations enhance the expression of oncogenic proteins and disrupt DNA damage control mechanisms and will finally result in the development of various NHL subtypes (69). To target these cells, cell surface Ags CD19, CD20 and CD30 are widely used targets (72).The diagnosis is established by tissue biopsy, followed by immunohistochemistry and genetic studies (71). Further evaluation of the disease progression can be obtained by staging systems, such as international prognostic index (IPI) and combined Positron Emission Tomography Computed Tomography (PET-CT) (73).

\section{Treatment Strategies for B-Cell Malignancies}

For fit patients, the combination of chemotherapy with corticosteroids remains the first line treatment for most of the listed malignancies. The anti-CD20 monoclonal $\mathrm{Ab}$ rituximab will be added for patients with CLL, B-cell NHL, and ALL. Patients that are ineligible for chemotherapy will be treated with specific pathway-inhibitors, such as Bruton tyrosine kinase (ibrutinib), B-cell lymphoma 2 (bcl-2) inhibitors (venetoclax), proteasome inhibitors (bortezomib, carfilzomib) or immunomodulating agents (lenalidomide, pomalidomide). For MM and Hodgkin lymphoma, monoclonal Abs are currently approved in the relapsed setting: daratumumab is the monoclonal $\mathrm{Ab}$ that binds to $\mathrm{CD} 38$, while brentuximab-vedotin is an Ab-drug conjugate that recognizes CD30. Autologous stem cell transplantation (SCT) will be performed at diagnosis for patients with MM or at relapse for NHL patients.

The efficacy of the initial therapy is evaluated by specific disease parameters and by minimal residual disease (MRD) status. MRD evaluation being negative is a strong indicator of prognosis-free survival while being positive suggests potential relapse (74). In case of disease relapse, a second line therapy is applied. Depending on the cancer type and relapse time, salvage therapy includes more and more specific pathway inhibitors that will be used in combination or in monotherapy. MRD determination has clinical implications in the treatment for ALL, where only MRD positive patients will undergo allogeneic SCT.

Current developments in immunotherapy, such as T-cell engaging BsAbs and chimeric Ag receptor T-cells (CAR-T), show promising results in the first clinical studies to enhance 


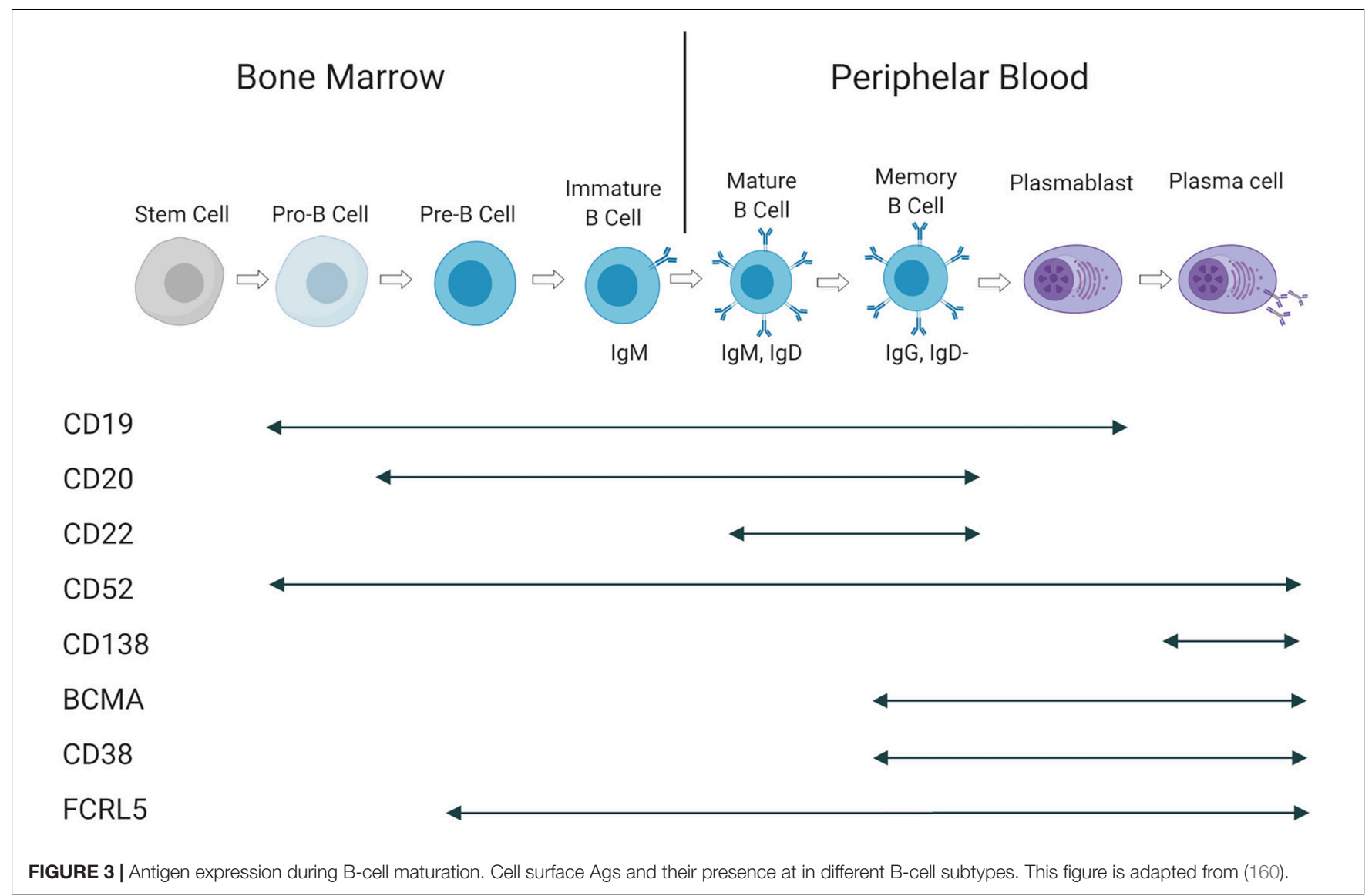

traditional approaches (75). The Ags expressed during B-cell development are illustrated in Figure 3. The clinical development of blinatumumab will be discussed later. CD19-binding CAR$\mathrm{T}$ cells were recently approved by the Food and Drug Administration (FDA) and the European Medicines Agency (EMA) for the treatment of relapsed ALL and aggressive NHL.

\section{BISPECIFIC ANTIBODIES IN CLINICAL DEVELOPMENT}

A selection of BsAbs in clinical development is shown in Table 3.

\section{Clinical Development for ALL, CLL, and/or NHL (CD19 - CD3)}

CD19 is expressed from the early development of B-cells up to their differentiation into plasma cells. Targeting CD19 results in $\mathrm{B}$-cell aplasia, which is considered as manageable since patients can receive intravenous Igs until the recovery of the B-cell lineage. When compared with other B-cell Ags, its broad expression profile and low negative regulation rate (76) makes CD19 a suitable target for B-cell malignancies. It is expressed in $80 \%$ of ALL cases, $88 \%$ of B-cell NHL and all cases of CLL (77).

Three main (anti-CD19 $\times$ CD3) BsAbs have been developed for the treatment of B-cell ALL: Blinatumumab, AMG103 (BiTE),
MGD011 (dual-affinity re-targeting Ab: DART) and AFM11 (Tandem diabody: TandAb).

\section{BiTE Anti-CD19 - CD3 (Blinatumomab; AMG103)}

Blinatumomab is a BiTE with excellent cell-binding capacities due to its small size allowing a better tumor penetration compared to Igs (78). In humans, it was initially explored in relapsed/refractory (r/r) NHL and afterwards in ALL (79). It was approved by the FDA in December 2014 and the EMA in December 2015 for the treatment of r/r Ph-negative ALL (23, 8083). However, it is currently being tested in clinical trials for other hematologic malignancies, such as NHL and MM.

Given its short half-life, blinatumomab is continuously administrated via an intravenous infusion, at a constant rate (after an increase in the initial dose) and by repeated cycles of 4 weeks, that are interrupted with 2 weeks without treatment (23). The observed side effects are mostly mild to moderate and occur during the first cycle. The treatment generally starts under vigilant monitoring with a lower dose during the first 7 days. The most commonly observed adverse effects are chills, pyrexia, constitutional symptoms and reversible neurological events, such as tremors, seizures, aphasia, and ataxia. Furthermore, up to $70 \%$ of patients had symptoms of a transient CRS (84). In order to minimize these effects, premedication with dexamethasone is required on the first day of each cycle and on the first day of any dose increase $(5,23)$. 
TABLE 4 | Clinical trials of BsAbs in combination with different immunotherapeutic strategies (selected trials).

\begin{tabular}{|c|c|c|c|}
\hline Names (Sponsors) & Targets & $\begin{array}{l}\text { Diseases } \\
\text { indication }\end{array}$ & Phase (NCT\#) \\
\hline \multicolumn{4}{|l|}{ Combinations with immune modulators } \\
\hline $\begin{array}{l}\text { Combination of Blinatumomab and Nivolumab (anti-PD-1 } \\
\text { mAb) }+ \text { /- Ipilimumab (anti-CTLA4 mAb) [National Cancer } \\
\text { Institute (NCl)] }\end{array}$ & CD3 $\times$ CD19 × PD-1 (x CTLA4) & B-ALL & $\begin{array}{l}\text { Phase } \\
\text { I (NCT02879695) }\end{array}$ \\
\hline $\begin{array}{l}\text { Combination of Blinatumomab and Pembrolizumab } \\
\text { (anti-PD-1 mAb) (Merck Sharp \& Dohme Corp., Amgen) }\end{array}$ & $\mathrm{CD} 3 \times \mathrm{CD} 19 \times \mathrm{PD}-1$ & B-ALL & $\begin{array}{l}\text { Phase I/II } \\
\text { (NCT03160079) }\end{array}$ \\
\hline $\begin{array}{l}\text { Combination of Blinatumomab and Pembrolizumab } \\
\text { (anti-PD-1 mAb) (Amgen) }\end{array}$ & $\mathrm{CD} 3 \times \mathrm{CD} 19 \times \mathrm{PD}-1$ & $\mathrm{NHL}$ & $\begin{array}{l}\text { Phase } \\
\text { I (NCT03340766) }\end{array}$ \\
\hline $\begin{array}{l}\text { Combination of Blinatumomab and (anti-PD-1 mAb) (City of } \\
\text { Hope Medical Center) }\end{array}$ & $\mathrm{CD} 3 \times \mathrm{CD} 19 \times \mathrm{PD}-1$ & ALL & $\begin{array}{l}\text { Phase I/II } \\
\text { (NCT03512405) }\end{array}$ \\
\hline $\begin{array}{l}\text { Combination of Blinatumomab and Pembrolizumab } \\
\text { (anti-PD-1 mAb) (Children's Hospital Medical Center, } \\
\text { Cincinnati) }\end{array}$ & $\mathrm{CD} 3 \times \mathrm{CD} 19 \times \mathrm{PD}-1$ & $\begin{array}{l}\text { B-cell lymphoma } \\
\text { and leukemia }\end{array}$ & $\begin{array}{l}\text { Phase } \\
\text { I (NCT03605589) }\end{array}$ \\
\hline $\begin{array}{l}\text { Combination of BTCT4465A and Atezolimumab } \\
\text { (anti-PD-L1 mAb) (Genentech) }\end{array}$ & $\mathrm{CD} 3 \times \mathrm{CD} 20 \times \mathrm{PD}-\mathrm{L} 1$ & CLL, NHL & $\begin{array}{l}\text { Phase I } \\
\text { (NCT02500407) }\end{array}$ \\
\hline $\begin{array}{l}\text { Combination of REGN1979 and REGN2810 (cemiplimab: } \\
\text { anti-PD-1 mAb) (Regeneron Pharmaceuticals) }\end{array}$ & $\mathrm{CD} 3 \times \mathrm{CD} 20 \times \mathrm{PD}-1$ & Lymphoma & $\begin{array}{l}\text { Phase I } \\
\text { (NCT02651662) }\end{array}$ \\
\hline $\begin{array}{l}\text { Combination of REGN1979 and REGN2810 (anti-PD-L1 } \\
\text { mAb) (Hoffmann-La Roche) }\end{array}$ & $\mathrm{CD} 3 \times \mathrm{CD} 20 \times \mathrm{PD}-\mathrm{L} 1$ & $\mathrm{NHL}$ & $\begin{array}{l}\text { Phase I } \\
\text { (NCT03533283) }\end{array}$ \\
\hline \multicolumn{4}{|l|}{ Combination with $\mathrm{mAb}$} \\
\hline $\begin{array}{l}\text { Combination of JNJ-64407564/JNJ-64007957 and } \\
\text { Daratumumab (Janssen) }\end{array}$ & $\mathrm{CD} 3 \times \mathrm{BCMA}$ or GPRC5D $\times$ CD38 & $\mathrm{MM}$ & $\begin{array}{l}\text { Phase I } \\
\text { (NCT04108195) }\end{array}$ \\
\hline \multicolumn{4}{|l|}{ Combination with ADC } \\
\hline $\begin{array}{l}\text { Combination of BTCT4465A and Polatuzumab vedotin } \\
\text { (anti-CD79b } \times \text { MMAE) (Hoffmann-La Roche) }\end{array}$ & $\mathrm{CD} 3 \times \mathrm{CD} 20 \times \mathrm{ADC}$ & B-cell NHL & $\begin{array}{l}\text { Phase I } \\
\text { (NCT03671018) }\end{array}$ \\
\hline
\end{tabular}

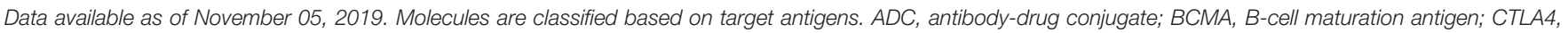

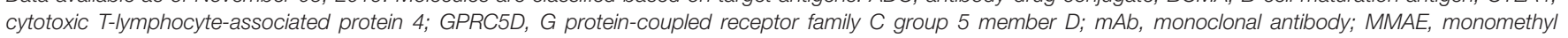
auristatin E; $P D-1$, programmed cell death 1; $P D-L 1$, programmed cell death 1 ligand.

Blinatumomab is currently in Phase I and II clinical trials in combination with monoclonal Abs (mAbs) targeting inhibitory checkpoints, such as programmed cell death protein 1 (PD-1) and cytotoxic T lymphocyte antigen 4 (CTLA-4) (Table 4).

\section{DART CD19 - CD3 (MGD011)}

MGD011 (duvortuxizumab) is a CD19 $\times$ CD3 DART with a silenced, human IgG1 Fc domain. The presence of this Fc domain prolongs its circulating half-life (approximately 14.3 to 20.6 days), similar to conventional mAbs, allowing for an administration every 2 weeks (85). The humanized Ab arms have a 10-fold greater affinity for CD19 than for CD3, thereby enabling preferential binding to target cells, while minimizing the engagement of CD3 in the absence of target cells. Although the preclinical results in murine NHL models was promising, the clinical development of MGD011 was discontinued early due to high levels of neurotoxicity observed in a Phase I study on the treatment of B-cell malignancies (NHL, CLL, and NCT02743546) (85).

\section{TandAb CD19 - CD3 (AFM11)}

AFM11 is a tetravalent bispecific TandAb with two binding sites for CD3 and two for CD19. This structure increases the binding affinities for CD19 and CD3 by approximately 5- and 100-fold, respectively, compared to those of BiTE. Furthermore, AFM11 potency is not correlated with CD19 density on the surface of the target cell (86). This BsAb was tested in phase I studies for the treatment of ALL (NCT02848911) and r/r NHL (NCT02106091). These two clinical trials were suspended due to neurological side effects that caused the death of one patient and life-threatening toxicities in two others. Therefore, the risk/benefit profile was not favorable with the dosing regimens studied, putting an end to these two clinical studies.

\section{Clinical Development for ALL, CLL, and/or NHL (CD20 - CD3)}

The CD20 Ag is expressed exclusively on mature B-cells and not on B-cell precursors, stem cells and plasma cells. It is also observed on the surface of malignant B-cells: more than $95 \%$ of $\mathrm{B}$-cells in NHL and other B-cell malignancies express CD20.

\section{TriFab CD20-CD3 (FBTA05)}

FBTA05 (Lymphomun) has a TriFAb format; the third functional site is the $\mathrm{Fc}$ region which provides an additional capacity to recruit accessory cells bearing the $\mathrm{Fc} \gamma$ receptor $(\mathrm{Fc} \gamma \mathrm{R})$ (macrophages, dendritic cells, NK-cells and neutrophil granulocytes) (87). Promising responses have already been observed in pediatric patients (88, 89), but details on its further development or its current status are not clear. 


\section{IgG4-Based CD20 - CD3 (REGN1979)}

REGN1979 is a fully humanized bispecific IgG4 Ab designed to resemble natural human Abs (90). As a result, this construct has the advantages of native Abs, such as stability, low aggregation propensity, low immunogenicity and good pharmacokinetics. This BsAb induces prolonged B-cell depletion in the peripheral blood as well as in lymphoid organs in preclinical models (90). In a phase I study on $\mathrm{r} / \mathrm{r}$ NHL, administration of BsAb resulted in an overall response of $100 \%$ in follicular lymphoma and provided a complete response in two patients who did not respond to CAR T-cell therapy (91).

\section{IgG1-Based CD20 - CD3 (Mosunetuzumab)}

Mosunetuzumab (or BTCT4465A) is a another full-length, humanized IgG1 molecule with an almost native $\mathrm{Ab}$ structure using $\mathrm{KiH}$ technology. The first clinical results with mosunetuzumab were recently reported: In the patients with $\mathrm{r} / \mathrm{r}$ aggressive NHL, the objective response rate (ORR) was $37.1 \%$, with a complete response rate of $19.4 \%$. Higher response were seen in the group with indolent NHLs with an ORR of $62.7 \%$ and complete response (CR) rate of $43.3 \%$ (92).

\section{CD20-CD3 (RG6026)}

RG6026 is a BsAb that binds to CD20 and CD3 in a 2:1 format, providing better affinity for the tumor Ag. The CD3 binding arm is fused directly to one of the CD20 binding arms via a short flexible linker. RG6026 also has a modified heterodimeric Fc region that prevents binding to $\mathrm{Fc} \gamma \mathrm{Rs}$, while binding to the neonatal Fc Receptor is maintained, which results for an extended circulatory half-life (93). It showed significant in vitro and in vivo activity even on cells expressing low levels of CD20, it remains active in the presence of competing anti-CD20 antibodies and can potentially bypass the resistance to rituximab (94). Furthermore, its cytotoxicity activity has been observed even at very low effector:target ratios (95).

Clinical trials are underway to evaluate the efficacy of these different anti-CD20 $\times$ anti-CD3 BsAbs (Table 3). Several of these CD20-targeting BsAbs (Mosunetuzumab, REGN1979, and RG6026, etc.) are currently in Phase I clinical trials in combination with monoclonal Abs targeting the PD-1 inhibitory checkpoint or its ligand, PD-L1 (Table 4).

\section{Clinical Development for Lymphoma (CD30 - CD16A)}

AFM13 is a tetravalent BsAb in the TandAb format without Fc domain (24). Therefore, it has two binding sites for CD30, located between two binding sites for CD16A. The center of the molecule interacts with the CD30 Ag, whereas the effector cell binds to both ends of the molecule. It is used to direct NK-cell toxicity to CD30-expressing lymphoma cells. It has been shown that AFM13 activates NK-cells only after binding to CD30 (94). AFM13 has shown signs of activity in a Phase I study, as well as effective NK-cell activation and a decrease in soluble CD30. Moreover, it has been well tolerated and may even be better tolerated than T-cell based BsAbs (24). AFM13 is currently in phase II clinical development (Table 3).

\section{Clinical Development for MM (CD38 - CD3)}

The uniformly overexpressed CD38 Ag is the most widely studied target in the treatment of MM (96). Intriguingly, it is also expressed by many other hematopoietic cells, but treatment with the monoclonal $\mathrm{Ab}$ daratumumab is safe and without major side effects (96).

Several humanized anti-CD38/CD3 XmAb BsAbs and with different affinities for $\mathrm{CD} 38$ and $\mathrm{CD} 3$, were simultaneously evaluated during the preclinical stage. The best in vitro and in vivo results were obtained with AMG424. Although it has a lower affinity for CD3 to prevent an uncontrolled CRS in the presence of soluble CD38, it shows strong anti-tumor effects (97). Given that CD38 is also expressed by T-cells, a fratricide problem could interfere with the activity of AMG424. A Phase I Study (NCT03445663) evaluating the safety, tolerability, pharmacokinetics, pharmacodynamics, and efficacy of AMG 424 in recurrent/refractory Multiple Myeloma ( $\mathrm{r} / \mathrm{r} \mathrm{MM}$ ) began in 2018 and will end in 2022.

GBR 1342 is another anti-CD38/CD3 BsAb that is developed by Glenmark. It contains a complete $\mathrm{Fc}$ domain with a reduced effector function. In preclinical studies, GBR1342 showed a more potent anti-cancer effect than the anti-CD38 $\mathrm{mAb}$ daratumumab. It efficiently recruited T-cells and induced CD38 + cell depletion in the blood and especially the bone marrow (98). A Phase I study (NCT03309111) started in October 2017 evaluating the safety and tolerability of GBR 1342 .

\section{Clinical Development for MM (BCMA - CD3)}

BCMA is a membrane Ag expressed by malignant plasma cells as well as plasmacytoid dendritic cells. In contrast, it is not expressed on naive B-cells, CD34 + hematopoietic cells or any other normal tissue cells (99-101). BCMA has several advantages making it a highly studied target as part of the treatment for MM. First, BCMA is highly expressed by MM cells, as well as in patients with poor prognosis. Second, a rapid re-emergence of B-cell immunity after the end of the anti-BCMA treatment would be possible since this Ag is not expressed early in B-cell development. Third, the lack of BCMA expression in other bone marrow populations prevents off-tumor toxicities.

Several BsAbs are currently in clinical trials to evaluate their efficacy primarily in patients with advanced MM who have relapsed or are refractory to standard treatment (Table 3).

\section{BCMA-CD3 BiTEs (AMG420 and 701)}

AMG420 (or BI 836909) is a BiTE that has a short halflife time and therefore must be administered intravenously for 4 weeks followed by 2 weeks treatment-free. While AMG420 induces potent lysis of BCMA-positive MM cells in vitro and in vivo, BCMA-negative cells were not affected. Accordingly, clinical trials started for the treatment of $\mathrm{r} / \mathrm{r} \mathrm{MM}$ in 2015 (NCT02514239) and in 2019 (NCT03836053) (102). In a phase I study including 42 refractory MM patients, a high response rate of 70\% was observed including 50\% MRD-negative complete responses. The most common side effects were infections and 
polyneuropathy. AMG701 is a half-life-extended BiTE that contains the single-chain variable fragments of AMG420. It is suitable for once-weekly dosing and is currently tested in a phase I trial. Comparison of the observed responses and toxicities, allows to study the clinical implications of such a half-life extension.

\section{BCMA-CD3 CrossMabs (EM801, CC-93269)}

EM801 is a CrossMab in the $2+1$ format. Its prolonged halflife due to maintenance of the Fc region allows for a convenient weekly intravenous treatment. Nonetheless, it is eliminated from the circulatory system within 1 to 2 months of treatment discontinuation. EM801 achieved lysis of $90 \%$ of myeloma cells after $48 \mathrm{~h}$ with a very low E:T ratio (103). The first results of a related molecule, EM901/CC-93269 (ENgMab/Celgene), on 30 r/r MM patients were recently presented: clinical activity was seen at higher doses of the drug with almost $90 \%$ of the patients responding at the highest dose. $76 \%$ of patients developed a CRS which was severe (> Grade 3) in one patient (104).

\section{IgG2a-Based BCMA-CD3 (PF-06863135)}

PF-06863135 (PF-3135) is a humanized BsAb using a IgG2a backbone with mutations in the $\mathrm{Fc}$ part that promote heavy chain heterodimer formation and reduce $\mathrm{Fc} \gamma$ receptor binding (105). This BsAb showed potent anti-myeloma activity in both in vitro and in vivo models and its toxicity profile in cynomolgus monkeys was acceptable (105). PF-06863135 is currently undergoing a Phase I study to assess its safety and tolerability (NCT03269136) (106).

\section{Clinical Development for MM (FcRL5 - CD3 and GPRC5D - CD3)}

Two new targets have recently emerged as part of the MM-related targets: Fc Receptor-Like 5 (FcRL5) and G-protein coupled receptor family C group 5 member D (GPRC5D).

The first (also known as FcRH5, IRTA2, or CD307) is a specific and exclusive surface marker of the B-cell lineage. Its expression is detected starting from the pre-B-cell stage (107). However, unlike other B-cell-specific surface proteins, FcRL5 expression is preserved in normal and malignant B-cells (including plasma cells). This suggests a potential broader applicability of this target in B-cell malignancies, such as chronic lymphocytic leukemia, mantle cell lymphoma, diffuse large B-cell lymphoma, and follicular lymphoma $(107,108)$.

In contrast, GPRC5D is expressed on the surface of malignant cells involved in multiple myeloma without being expressed at appreciable levels by normal hematopoietic cells, such as T-cells, NK-cells, monocytes, granulocytes and bone marrow progenitors, including hematopoietic stem cells (109). High mRNA expression of GPRC5D was observed in patients with MM, whereas only low expression was detected in normal tissues. Its mRNA expression was also significantly correlated with poor overall survival rates (110). As a result, its very limited expression profile makes it a suitable target in MM treatment.

Two BsAbs have been developed against these two targets and are currently in a phase I clinical trial: RG6160 which targets FcRL5 (NCT03275103) and the DuoBody JNJ-64407564 which targets GPRC5D (NCT03399799) (Table 3). Both showed in vitro and in vivo B-cell depletion and tumor growth suppression in myeloma models $(35,109)$.

\section{CONCERNS IN CLINICAL DEVELOPMENT}

\section{Cytokine Release Syndrome (CRS)}

CRS is a potentially fatal systemic inflammatory reaction that is observed after the infusion of immunotherapeutic agents (monoclonal Abs, BsAbs, and CARs). Although our understanding of CRS is incomplete, different immune populations including T-lymphocytes, monocytes and macrophages are activated, all resulting in a mass production of inflammatory cytokines, particularly interleukin (IL)-6 and interferon (IFN) $-\gamma$ (111). Although the immunological cascade is initiated by T-cell activation, this massive systemic production of toxic cytokines is mainly due to monocyte and macrophage activation. T-cell IFN- $\gamma$, macrophage IL-6, IL-10 and tumor necrosis factor alpha (TNF- $\alpha$ ) seem to cooperate to facilitate this cytokine release (112). In addition, IL- 6 has been shown to play a central role in humans and mice in the development of CRS $(111,113)$. Patients presenting CRS usually develop mild fatigue, fever, chills, headache, arthralgia, or even more serious life-threatening problems, such as hypotension, tachycardia, vascular leaks and circulatory collapse during or immediately following administration of the drug.

In general, signs and symptoms of CRS only appear during the first cycle of the drug, and not later during subsequent administrations. This CRS is not implicated in the mechanisms of action of T-cell directed immunotherapies (114), as the response to treatment is unaffected by the severity of CRS (115). A mitigation strategy based on corticosteroids and IL6 blockade has been proposed to minimize the release of toxic cytokines (112).

An alternative way to avoid CRS-related problems is to dissociate tumor cell destruction and cytokine release. There are two distinct thresholds for T-cell activation based on the number of TCR-peptide-MHC (pMHC) complexes formed (116). The formation of two TCR-pMHC complexes is sufficient between a T-cell and an Ag-presenting cell, to trigger T-cell-mediated cell lysis. On the other hand, 10 TCR-pMHC complexes are required for the formation of a complete immune synapse and cytokine secretion. Thus, adjusting the binding characteristics for the CD3-binding arm, a BsAb could more closely mimic the natural TCR-pMHC induced T-cell activation (117). Consequently, new CD3-binding Abs have been generated that bind to multiple epitopes on CD3 with a wide range of affinities and agonist activities. Functional studies were realized with BsAbs that integrated the different CD3-binding domains. A BsAb with a new T-cell-engaging domain could be created that elicited strong in vivo tumor cell killing and low levels of cytokine release (118).

\section{Neurotoxicity}

Neurotoxicity is the second most common adverse effect observed with different BsAbs. Symptoms may range from subtle changes in personality to tremors, vertigo, confusion, 
and focal neurological symptoms to more serious episodes of encephalopathy, ataxia, cerebellar alteration, convulsions and delirium (23). The pathophysiology of these neurotoxic effects still has not been determined but, as in CRS, inflammatory cytokines appear to be involved (119).

Grade 3 or higher neurotoxicity occurs in approximately 10 to $20 \%$ of the patients treated with blinatumomab $(5,120)$. However, in most cases, the neurological side effects were reversible after stopping the BsAb perfusion and initiation of corticosteroids. Furthermore, grade 3 or higher neurological events were avoided using a progressive dosing regimen and the prophylactic administration of dexamethasone. Although the application of steroids relieves the central nervous system symptoms, it could potentially hamper the immune response. While reduced levels of inflammatory cytokines were produced by dexamethasone-treated T-cells, there was no inhibitory effect of dexamethasone on the cytotoxic capacities of T-cells observed (121). This indicates that dexamethasone does not interfere with the therapeutic efficacy of BsAbs.

\section{Administration Route}

The most commonly used administration route for BsAbs is intravenous (IV) perfusion. Although it has advantages in terms of pharmacokinetics and pharmacodynamics, it has certain drawbacks with regards to patient convenience, access to therapeutic targets and cost of treatment. The reduced half-life time of some BsAbs results in either more frequent administrations or continuous infusion $(11,12)$. On the other hand, the addition of an Fc domain facilitates the BsAb purification, improves solubility and stability, and molecule's half-life (12). However, although BsAbs with an extended halflife may ease the logistics of administration, prolonged exposure could potentially increase the toxicity. Ongoing clinical trials will test this hypothesis and confirm or refute it.

\section{Resistance Mechanisms \\ T-Cell Exhaustion/Dysfunction}

During cancer development, T-cells rapidly become dysfunctional due to persistent Ag-exposure. This reduces their proliferation capacity and their cytotoxic effector function. Moreover, several inhibitory receptors (such as PD-1, CTLA4, T-cell immunoglobulin and mucin domain-3 (TIM-3), Lymphocyte-activation gene 3 (LAG-3), T-cell immunoglobulin and ITIM domain (TIGIT) are overexpressed by malignant cells $(122,123)$. Among them, the PD1/PD-L1 axis appears to be a central process in T-cell dysfunction (124). Targeting these inhibitory pathways is currently used to block immune suppressive signals coming from tumor cells and to prolong T-cell activation.

T-cell exhaustion is characterized by a progressive loss of function, such as proliferation, cytokine production, and cell lysis. T-cells do not become totally inactive, but fail to effectively eradicate cancer cells. Three distinct signals are normally required for optimal T-cell activation and proliferation. First, an Ag recognition via the TCRs is needed, followed by a costimulation and a cytokine release by the T-cells, which is required for their expansion. BsAb only provide the first signal.
However, BiTEs and many other $\mathrm{Ab}$ formats may trigger the formation of an effective immunological synapse, abolishing the need for co-stimulation (125). Co-activation of T-cells through CD28 or $4-1 \mathrm{BB}$, will increase the activation of T-cells by BsAbs $(126,127)$. Regarding the third requirement, new BsAb constructs have been developed to include cytokine IL-15 (128). Moreover, as mentioned previously, the blockade of PD-1 or its ligand, PD-L1, can successfully reactivate T-cell function.

Unfortunately, most patients do not maintain sustainable responses to this treatment. The lack of a sustainable response can be at least partly explained by the presence of other inhibitory pathways in T-cells. Thus, the identification of resistance and evasion mechanisms as well as the understanding of the processes that direct and maintain the various dysfunctional T-cell states are still a major concern for enabling effective BsAb activity targeting T-cells, while avoiding potentially life-threatening autoimmune side effects (129).

\section{Antigen Escape}

Tumor cells can also downregulate a targeted Ag and circumvent immune recognition during treatment. For example, loss of CD19 has been observed in patients with ALL, contributing to progression of the leukemia in 10 to $20 \%$ of cases. Altered membrane traffic and export (130) as well as, acquired mutations and alternative splicing explain this loss of expression at the cell-surface, while its intracellular abundance is preserved (131). Alternative splicing can, for example, result in the loss of CD19 extracellular domain (131). This leads to a conformational change in the extracellular domain of CD19, while the loss of a chaperone molecule (CD81) can lead to the intracellular accumulation of CD19 (130).

Consequently, a potential strategy to control Ag escape is to combine the targeting of several Ags in order to generate $\mathrm{T}$ lymphocytes that can recognize several Ags expressed on the tumor cells. For instance, a clinical study evaluating the efficacy of an anti-CD19/anti-CD22 BsAb is currently ongoing (NCT02370160) (132) (Table 3).

\section{Immunosuppressive Microenvironment}

Another major concern is the possible involvement of tumor microenvironment factors, such as immunosuppressive regulatory $\mathrm{T}$ lymphocytes (Tregs). Given that BsAbs trigger T-cell activation via binding to the CD3 complex, other $\mathrm{T}$ lymphocyte cell subtypes, besides effector $\mathrm{T}$ lymphocytes, will also be activated (133). A high percentage of Tregs present in the tumor environment predicts a resistance to treatment. For example, Tregs, activated by blinatumomab, are able to suppress the proliferation of effector T-cells and the subsequent cell lysis. As a result, T-cell depletion prior to administration of blinatumomab may increase effectiveness for non-responding patients treated with blinatumomab (19).

\section{Immune Checkpoint Receptor PD-1}

PD-1 is a co-inhibitory receptor that acts as an immune checkpoint. It is used to attenuate immune responses by limiting the duration and intensity of the immune reaction. Tumor cells often express its ligand, PD-L1, to evade immune system 
attacks (134). It is an adaptive mechanism of immune escape in response to pro-inflammatory cytokines (135). A wide range of anti-PD-1 antibodies (nivolumab, pembrolizumab) or antiPD-L1 antibodies (atezolizumab, durvalumab, avelumab) have been tested in mono- or in combination therapy (136). However, $\mathrm{PD}-\mathrm{L} 1$ is widely expressed on healthy tissues and therefore, the efficacy of these blocking Abs can be reduced due to binding to PD-L1 positive normal cells. This may lead to blind activation of T-cells, including those involved in (auto)immune-related adverse events such as endocrinopathy (for example, thyroiditis), dermatitis, pneumonia, hepatitis, and colitis (137-139).

Immune modulation through PD-1 is one of the mechanisms of resistance to blinatumomab (140). While refractory leukemic blasts overexpressed PD-L1, T-cell exhaustion was observed with overexpression of PD-1. Combination of blinatumomab and the anti-PD-1 antibody Pembrolizumab enhanced T-cell function and induced an anti-leukemic response in a 12-year-old patient with refractory ALL (140). The activity of blinatumomab could also be restored by adding an anti-PD-L1 $\times$ CD28 BsAb that abolished the PD-L1 mediated resistance and even reverted the negative PD-L1 signaling into positive costimulation through CD28 on T-cells (141). The combined action of PD-1/PDL1 blocking Abs and BsAbs inspired the design and initiation of clinical studies combining blinatumomab with checkpoint inhibition as summarized in Table 4. In order to improve the clinical benefit, BsAbs that simultaneously target two immune checkpoints have been developed. For example, the dual blockade of PD-1 and LAG-3 with monoclonal Abs further suppresses T-cell activation. For instance, an anti-PD-1/anti-LAG-3 DART, called MGD013, binds specifically to both PD-1 and LAG-3 (142). Blocking both pathways enhanced T-cell responses compared to those observed upon independent blockade of either the PD1 or LAG-3 pathways alone. The BsAb KN046 is another that binds to PD-L1 on the tumor cells and to CTLA-4 expressed by the T-cells. However, the increase in anti-tumor activity has been associated with a significant increase in the number of adverse events due to over-activation of the immune system. Consequently, a new approach is currently being investigated. It consists in the deletion of the PD-1 pathway via high-affinity PD-1 binding, while inhibiting CTLA-4 with a low affinity binding arm. This construct inhibits CTLA-4 in double-positive T-cells while reducing the binding to peripheral $\mathrm{T}$ lymphocytes expressing CTLA-4, resulting in better tolerability (143).

\section{The Co-stimulatory Receptor 4-1BB}

4-1BB (CD137) is a potent co-stimulatory receptor that is upregulated on effector $\mathrm{T}$ lymphocytes including tumor infiltrating T-cells. Its stimulation improves cytotoxic function, as well as the induction of an immunological memory (144). In addition to its function on T-cells, it has been shown to improve the cytotoxic function of NK-cells (145). 4-1BBbinding monoclonal Abs are classified according to their agonistic capacities and Fc receptor affinities. While urelumab is a strong agonist and inducing signal activation without Fc receptor binding, the basal agonistic activity of utomilumab is weak but increases after Fc receptor crosslinking (146). The clinical development of these first-generation Abs was stopped: utomilulab showed only a reduced efficacy (although no major toxicities were seen) and urelumab showed efficacy but also severe liver toxicity $(147,148)$. Interestingly, new $4-1 B B$ binding Abs have recently been created by adapting the level of intrinsic agonistic activity, the Fc $\gamma \mathrm{R}$ interactions, the IgG subclass and Ab affinities $(146,149)$. Another strategy to overcome the limitations of the first- generation Abs is the integration of 4-1BB-binding domains in BsAbs.

A few BsAbs containing a tumor Ag-binding fragment and a 4-1BB agonist have been developed (150-152). The main characteristic of these compounds is the lack of significant 4$1 \mathrm{BB}$ activation in the absence of tumor Ag binding, ensuring tumor-localized immune activation. For example, a BsAb that simultaneously targets $4-1 \mathrm{BB}$ and the CD19 tumor Ag was developed for systemic administration (153). Since additional mutations in the Fc region prevents Fc $\gamma$ receptor cross-linking, the $4-1 \mathrm{BB}$ in this construct is only activated when crosslinked to CD19 and thus, hepatic toxicity is avoided (9). Another example of BsAb targeting checkpoint agonists is INBRX-105 (Inhibrx) which is directed toward PD-L1 and 4-1BB. While simultaneously suppressing inhibition via the PD-1 - PD-L1 axis, it is designed to only activate T-cells via $4-1 \mathrm{BB}$ in the tumor environment when it encounters PD-L1 (17).

\section{Immune Checkpoint Receptor CD47}

CD47 [Integrin-associated protein (IAP)] is ubiquitously expressed in normal tissues and can be found on mesenchymal stromal cells and blood cells, particularly erythrocytes and platelets, and is generally upregulated in cancers. When it binds to its ligand, the signal regulatory protein $\alpha(\operatorname{SIRP} \alpha)$ which is an inhibitory receptor on macrophages and dendritic cells, CD47 sends "don't eat me" signals by inhibiting phagocytosis of tumor cells and triggering an immune evasion (154).

Hematological cancer cells overexpress CD47 in order to evade removal by phagocytes (macrophages and dendritic cells) $(154,155)$. As a consequence, both the innate and adaptive anti-cancer immune responses are suppressed. Therefore, CD47 neutralizing antibodies could improve tumor lysis by effector cells. However, CD47 is also widely expressed on normal cells (156). Thus, a general blockade of the CD47/SIRP $\alpha$ interaction may result in the removal of normal healthy cells and may be associated with toxicity.

Furthermore, the abundant expression of CD47 throughout the entire human body could eventually lead to the formation of "Ag sinks" that would prevent anti-CD47 antibodies from reaching the targeted tumor. To circumvent this problem, BsAbs with a low affinity for CD47 and a high affinity for a tumor Ag have been developed, which guarantee CD47 to be bound by BsAb only on tumor cells co-expressing both Ags. For example, a CD47 × CD19 BsAb (TG-1801, NI-1701, NovImmune, TG Therapeutics) induced increased phagocytosis by $\mathrm{Fc}$ and retained its activity in the presence of high amounts of non-tumor-associated CD47 (157). However, the functional Fc domains present in this BsAb can cause the off-target premature activation of $\mathrm{Fc}$ receptor $(\mathrm{FcR})$-expressing phagocytes, thereby causing systemic toxicity. Another BsAb format called 
RTX-CD47, targeting CD47 and CD20 without an Fc domain, triggered a significant phagocytic removal of both CD20 and CD47 malignant B-cells, but not cells expressing CD47 alone, while preventing toxicity associated with the presence of an Fc domain (158).

\section{CONCLUSION}

As seen in different clinical trials, BsAbs are promising tools for the treatment of hematologic B-cell malignancies. They enable different mechanisms of action, each having its own advantages and disadvantages. Although anti-tumor effects are observed, their clinical translation is hampered by limiting side-effects, such as off-target effects, a reduced E:T ratio in pretreated patients, and pharmacological limitations. Therefore, combined expertise in immunology, pharmacology and $\mathrm{Ab}$ engineering is required to improve their efficacy. A number of approaches are currently being studied and include combinations with checkpoint inhibitors, chemotherapy and other existing treatments. The different platforms on which BsAbs are produced will further improve their anti-tumor activity. Looking at the variety of targets, indications, mechanisms of action and implicated companies, it is clear that BsAbs will become key players in the field of immunotherapy.

\section{REFERENCES}

1. Perez P, Hoffman RW, Shaw S, Bluestone JA, Segal DM. Specific targeting of cytotoxic T cells by anti-T3 linked to anti-target cell antibody. Nature. (1985) 316:354-6.

2. De Gast GC, Van Houten AA, Haagen IA, Klein S, De Weger RA, Van Dijk A, et al. Clinical experience with CD3 x CD19 bispecific antibodies in patients with B cell malignancies. J Hematother. (1995) 4:433-7.

3. Heiss MM, Murawa P, Koralewski P, Kutarska E, Kolesnik OO, Ivanchenko $\mathrm{VV}$, et al. The trifunctional antibody catumaxomab for the treatment of malignant ascites due to epithelial cancer: results of a prospective randomized phase II/III trial. Int J Cancer. (2010) 127:2209-21. doi: 10.1002/ijc.25423

4. Spiess C, Zhai Q, Carter PJ. Alternative molecular formats and therapeutic applications for bispecific antibodies. Mol Immunol. (2015) 67(2 Pt A):95106.

5. Kantarjian H, Stein A, Gokbuget N, Fielding AK, Schuh AC, Ribera J-M, et al. Blinatumomab versus chemotherapy for advanced acute lymphoblastic leukemia. $N$ Engl J Med. (2017) 376:836-47. doi: 10.1056/NEJMoa160 9783

6. Brinkmann U, Kontermann RE. The making of bispecific antibodies. MAbs. (2017) 9:182-212. doi: 10.1080/19420862.2016.1268307

7. Foster LH, Lum LG. Treatment of hematological malignancies with $\mathrm{T}$ cell redirected bispecific antibodies: current status and future needs. Expert Opin Biol Ther. (2019) 19:707-20. doi: 10.1080/14712598.2019.1604672

8. Thakur A, Huang M, Lum LG. Bispecific antibody based therapeutics: strengths and challenges. Blood Rev. (2018) 32:339-47. doi: 10.1016/j.blre. 2018.02.004

9. Schlothauer T, Herter S, Koller CF, Grau-Richards S, Steinhart V, Spick C, et al. Novel human IgG1 and IgG4 Fc-engineered antibodies with completely abolished immune effector functions. Protein Eng Des Sel. (2016) 29:457-66. doi: 10.1093/protein/gzw040

10. Ridgway JB, Presta LG, Carter P. "Knobs-into-holes" engineering of antibody CH3 domains for heavy chain heterodimerization. Protein Eng. (1996) 9:61721.

11. Klinger M, Brandl C, Zugmaier G, Hijazi Y, Bargou RC, Topp MS, et al. Immunopharmacologic response of patients with B-lineage acute lymphoblastic leukemia to continuous infusion of $\mathrm{T}$ cell-engaging

\section{AUTHOR CONTRIBUTIONS}

JC and ML contributed to the conception and design of this review. ML and MK wrote the first draft of the manuscript. All authors contributed to manuscript revision, read, and approved the submitted version.

\section{FUNDING}

This work was supported by grants from the Belgian Foundation Against Cancer, Fonds d'Investissement de Recherche Scientifique (FIRS, CHU of Liege), the Fonds National de la Recherche Scientifique (FNRS, Belgium), Fondation Véronique Cornet and the Fonds Spéciaux de la Recherche (University of Liège). $\mathrm{ML}$ is a FNRS-TELEVIE fellow, ED a FNRS fellow. JC was supported by the Fondation Contre le Cancer.

\section{ACKNOWLEDGMENTS}

The authors thank the Véronique Cornet Foundation for their help and warm support.

CD19/CD3-bispecific BiTE antibody blinatumomab. Blood.

(2012) 119:6226-33. doi: 10.1182/blood-2012-01-400515

12. Kontermann RE, Brinkmann U. Bispecific antibodies. Drug Discov Today. (2015) 20:838-47. doi: 10.1016/j.drudis.2015.02.008

13. Pan H, Liu J, Deng W, Xing J, Li Q, Wang Z. Site-specific PEGylation of an anti-CEA/CD3 bispecific antibody improves its antitumor efficacy. Int $J$ Nanomedicine. (2018) 13:3189-201. doi: 10.2147/IJN.S164542

14. Rath T, Baker K, Dumont JA, Peters RT, Jiang H, Qiao S-W, et al. Fc-fusion proteins and FcRn: structural insights for longer-lasting and more effective therapeutics. Crit Rev Biotechnol. (2015) 35:235-54. doi: 10.3109/07388551. 2013.834293

15. Stork R, Campigna E, Robert B, Muller D, Kontermann RE. Biodistribution of a bispecific single-chain diabody and its half-life extended derivatives. $J$ Biol Chem. (2009) 284:25612-9. doi: 10.1074/jbc.M109.027078

16. Hutt M, Farber-Schwarz A, Unverdorben F, Richter F, Kontermann RE. Plasma half-life extension of small recombinant antibodies by fusion to immunoglobulin-binding domains. J Biol Chem. (2012) 287:4462-9. doi: 10.1074/jbc.M111.311522

17. Labrijn AF, Janmaat ML, Reichert JM, Parren PWHI. Bispecific antibodies: a mechanistic review of the pipeline. Nat Rev Drug Discov. (2019) 18:585-608. doi: 10.1038/s41573-019-0028-1

18. Tita-Nwa F, Moldenhauer G, Herbst M, Kleist C, Ho AD, Kornacker M. Cytokine-induced killer cells targeted by the novel bispecific antibody CD19xCD5 (HD37xT5.16) efficiently lyse B-lymphoma cells. Cancer Immunol Immunother. (2007) 56:1911-20.

19. Duell J, Dittrich M, Bedke T, Mueller T, Eisele F, Rosenwald A, et al. Frequency of regulatory $\mathrm{T}$ cells determines the outcome of the T-cellengaging antibody blinatumomab in patients with B-precursor ALL. Leukemia. (2017) 31:2181-90. doi: 10.1038/leu.2017.41

20. Smits NC, Sentman CL. Bispecific T-Cell engagers (BiTEs) as treatment of B-cell lymphoma. J Clin Oncol. (2016) 34:1131-3.

21. Stieglmaier J, Benjamin J, Nagorsen D. Utilizing the BiTE (bispecific T-cell engager) platform for immunotherapy of cancer. Expert Opin Biol Ther. (2015) 15:1093-9. doi: 10.1517/14712598.2015.1041373

22. Bargou R, Leo E, Zugmaier G, Klinger M, Goebeler M, Knop S, et al. Tumor regression in cancer patients by very low doses of a T cell-engaging antibody. Science. (2008) 321:974-7. doi: 10.1126/science.1158545 
23. Topp MS, Gokbuget N, Stein AS, Zugmaier G, O’Brien S, Bargou RC, et al. Safety and activity of blinatumomab for adult patients with relapsed or refractory B-precursor acute lymphoblastic leukaemia: a multicentre, single-arm, phase 2 study. Lancet Oncol. (2015) 16:57-66. doi: 10.1016/S1470-2045(14) 71170-2

24. Rothe A, Sasse S, Topp MS, Eichenauer DA, Hummel H, Reiners KS, et al. A phase 1 study of the bispecific anti-CD30/CD16A antibody construct AFM13 in patients with relapsed or refractory Hodgkin lymphoma. Blood. (2015) 125:4024-31. doi: 10.1182/blood-2014-12-614636

25. Pittari G, Filippini P, Gentilcore G, Grivel J-C, Rutella S. Revving up natural killer cells and cytokine-induced killer cells against hematological malignancies. Front Immunol. (2015) 6:230. doi: 10.3389/fimmu.2015.00230

26. Chretien A-S, Le Roy A, Vey N, Prebet T, Blaise D, Fauriat C, et al. Cancer-induced alterations of NK-mediated target recognition: current and investigational pharmacological strategies aiming at restoring NK-mediated anti-tumor activity. Front Immunol. (2014) 5:122. doi: 10.3389/fimmu.2014. 00122

27. Selvaraj P, Carpen O, Hibbs ML, Springer TA. Natural killer cell and granulocyte Fc gamma receptor III (CD16) differ in membrane anchor and signal transduction. J Immunol. (1989) 143:3283-8.

28. Grzywacz B, Kataria N, Verneris MR. CD56(dim)CD16(+) NK cells downregulate CD16 following target cell induced activation of matrix metalloproteinases. Leukemia. (2007) 21:356-9; author reply 359.

29. Romee R, Foley B, Lenvik T, Wang Y, Zhang B, Ankarlo D, et al. NK cell CD16 surface expression and function is regulated by a disintegrin and metalloprotease-17 (ADAM17). Blood. (2013) 121:3599-608. doi: 10.1182/ blood-2012-04-425397

30. Gauthier L, Morel A, Anceriz N, Rossi B, Blanchard-Alvarez A, Grondin $\mathrm{G}$, et al. Multifunctional natural killer cell engagers targeting NKp46 trigger protective tumor immunity. Cell. (2019) 177:1701-13.e16. doi: 10.1016/j.cell. 2019.04.041

31. Miller JS, Felice M, McElmurry R, McCullar V, Zhou X, Tolar J, et al. Trispecific killer engagers (TriKEs) that contain IL-15 to make NK cells antigen specific and to sustain their persistence and expansion. Blood. (2015) 126:232.

32. Ilyas S, Yang JC. Landscape of tumor antigens in T cell immunotherapy. $J$ Immunol. (2015) 195:5117-22. doi: 10.4049/jimmunol.1501657

33. Valent P, Sadovnik I, Eisenwort G, Bauer K, Herrmann H, Gleixner KV, et al. Immunotherapy-based targeting and elimination of leukemic stem cells in AML and CML. Int J Mol Sci. (2019) 20:4233. doi: 10.3390/ijms20174233

34. Bluemel C, Hausmann S, Fluhr P, Sriskandarajah M, Stallcup WB, Baeuerle $\mathrm{PA}$, et al. Epitope distance to the target cell membrane and antigen size determine the potency of $\mathrm{T}$ cell-mediated lysis by BiTE antibodies specific for a large melanoma surface antigen. Cancer Immunol Immunother. (2010) 59:1197-209. doi: 10.1007/s00262-010-0844-y

35. Li J, Stagg NJ, Johnston J, Harris MJ, Menzies SA, DiCara D, et al. Membraneproximal epitope facilitates efficient $\mathrm{T}$ cell synapse formation by antiFcRH5/CD3 and is a requirement for myeloma cell killing. Cancer Cell. (2017) 31:383-95. doi: 10.1016/j.ccell.2017.02.001

36. Duell J, Lammers PE, Djuretic I, Chunyk AG, Alekar S, Jacobs I, et al. Bispecific antibodies in the treatment of hematologic malignancies. Clin Pharmacol Ther. (2019) 106:781-91. doi: 10.1002/cpt.1396

37. Paul S, Kantarjian H, Jabbour EJ. Adult acute lymphoblastic leukemia. Mayo Clin Proc. (2016) 91:1645-66. doi: 10.1016/j.mayocp.2016.09.010

38. Rowe JM. Prognostic factors in adult acute lymphoblastic leukaemia. $\mathrm{Br} \mathrm{J}$ Haematol. (2010) 150:389-405. doi: 10.1111/j.1365-2141.2010.08246.x

39. Siegel R, Naishadham D, Jemal A. Cancer statistics, 2013. CA Cancer J Clin. (2013) 63:11-30. doi: 10.3322/caac.21166

40. Chiaretti S, Zini G, Bassan R. Diagnosis and subclassification of acute lymphoblastic leukemia. Mediterr J Hematol Infect Dis. (2014) 6:e2014073. doi: 10.4084/MJHID.2014.073

41. Wyatt KD, Bram RJ. Immunotherapy in pediatric B-cell acute lymphoblastic leukemia. Hum Immunol. (2019) 80:400-8. doi: 10.1016/j.humimm.2019. 01.011

42. Biondi A, Cazzaniga G. Novel clinical trials for pediatric leukemias: lessons learned from genomic analyses. Hematol Am Soc Hematol Educ Program. (2013) 2013:612-9. doi: 10.1182/asheducation-2013.1.612
43. Pui C-H, Mullighan CG, Evans WE, Relling MV. Pediatric acute lymphoblastic leukemia: where are we going and how do we get there? Blood. (2012) 120:1165-74. doi: 10.1182/blood-2012-05-378943

44. Alvarnas JC, Brown PA, Aoun P, Ballen KK, Barta SK, Borate U, et al. Acute lymphoblastic leukemia, version 22015. J Natl Compr Canc Netw. (2015) 13:1240-79.

45. Tatar A-S, Nagy-Simon T, Tomuleasa C, Boca S, Astilean S. Nanomedicine approaches in acute lymphoblastic leukemia. J Control Release. (2016) 238:123-38. doi: 10.1016/j.jconrel.2016.07.035

46. Scarfo L, Ferreri AJM, Ghia P. Chronic lymphocytic leukaemia. Crit Rev Oncol Hematol. (2016) 104:169-82. doi: 10.1016/j.critrevonc.2016.06.003

47. Hallek M, Shanafelt TD, Eichhorst B. Chronic lymphocytic leukaemia. Lancet (London, England). (2018) 391:1524-37.

48. Rossi D, Bruscaggin A, Spina V, Rasi S, Khiabanian H, Messina M, et al. Mutations of the SF3B1 splicing factor in chronic lymphocytic leukemia: association with progression and fludarabine-refractoriness. Blood. (2011) 118:6904-8. doi: 10.1182/blood-2011-08-373159

49. Rossi D, Fangazio M, Rasi S, Vaisitti T, Monti S, Cresta S, et al. Disruption of BIRC3 associates with fludarabine chemorefractoriness in TP53 wildtype chronic lymphocytic leukemia. Blood. (2012) 119:2854-62. doi: 10.1182/ blood-2011-12-395673

50. Villamor N, Conde L, Martinez-Trillos A, Cazorla M, Navarro A, Bea S, et al. NOTCH1 mutations identify a genetic subgroup of chronic lymphocytic leukemia patients with high risk of transformation and poor outcome. Leukemia. (2013) 27:1100-6. doi: 10.1038/leu.2012.357

51. Bullrich F, Rasio D, Kitada S, Starostik P, Kipps T, Keating M, et al. ATM mutations in B-cell chronic lymphocytic leukemia. Cancer Res. (1999) 59:247.

52. Dohner H, Stilgenbauer S, Benner A, Leupolt E, Krober A, Bullinger L, et al. Genomic aberrations and survival in chronic lymphocytic leukemia. $N$ Engl J Med. (2000) 343:1910-6.

53. Gaidano G, Foa R, Dalla-Favera R. Molecular pathogenesis of chronic lymphocytic leukemia. J Clin Invest. (2012) 122:3432-8. doi: 10.1172/ JCI64101

54. Klein U, Lia M, Crespo M, Siegel R, Shen Q, Mo T, et al. The DLEU2/miR15a/16-1 cluster controls B cell proliferation and its deletion leads to chronic lymphocytic leukemia. Cancer Cell. (2010) 17:28-40. doi: 10.1016/j.ccr.2009. 11.019

55. Hallek M, Cheson BD, Catovsky D, Caligaris-Cappio F, Dighiero G, Dohner $\mathrm{H}$, et al. Guidelines for the diagnosis and treatment of chronic lymphocytic leukemia: a report from the International workshop on chronic lymphocytic leukemia updating the national cancer institute-working group 1996 guidelines. Blood. (2008) 111:5446-56. doi: 10.1182/blood-2007-06093906

56. Brigle K, Rogers B. Pathobiology and diagnosis of multiple myeloma. Semin Oncol Nurs. (2017) 33:225-36. doi: 10.1016/j.soncn.2017.05.012

57. Usmani SZ, Hoering A, Cavo M, Miguel JS, Goldschimdt H, Hajek R, et al. Clinical predictors of long-term survival in newly diagnosed transplant eligible multiple myeloma - an IMWG Research Project. Blood Cancer J. (2018) 8:123. doi: 10.1038/s41408-018-0155-7

58. Caers J, Fernandez de Larrea C, Leleu X, Heusschen R, Zojer N, Decaux O, et al. the changing landscape of smoldering multiple myeloma: a European perspective. Oncologist. (2016) 21:333-42. doi: 10.1634/theoncologist.20150303

59. Kyle RA, Durie BGM, Rajkumar SV, Landgren O, Blade J, Merlini G, et al. Monoclonal gammopathy of undetermined significance (MGUS) and smoldering (asymptomatic) multiple myeloma: IMWG consensus perspectives risk factors for progression and guidelines for monitoring and management. Leukemia. (2010) 24:1121-7. doi: 10.1038/leu.2010.60

60. Hakim O, Resch W, Yamane A, Klein I, Kieffer-Kwon K-R, Jankovic M, et al. DNA damage defines sites of recurrent chromosomal translocations in B lymphocytes. Nature. (2012) 484:69-74. doi: 10.1038/nature10909

61. Walker BA, Boyle EM, Wardell CP, Murison A, Begum DB, Dahir NM, et al. Mutational spectrum, copy number changes, and outcome: results of a sequencing study of patients with newly diagnosed myeloma. J Clin Oncol. (2015) 33:3911-20. doi: 10.1200/JCO.2014.59.1503

62. Bianchi G, Munshi NC. Pathogenesis beyond the cancer clone(s) in multiple myeloma. Blood. (2015) 125:3049-58. doi: 10.1182/blood-2014-11-568881 
63. Bolli N, Avet-Loiseau H, Wedge DC, Van Loo P, Alexandrov LB, Martincorena I, et al. Heterogeneity of genomic evolution and mutational profiles in multiple myeloma. Nat Commun. (2014) 5:2997. doi: 10.1038/ ncomms 3997

64. Caers J, Garderet L, Martin Kortüm K, O’Dwyer ME, van de Donk NWCJ, Binder M, et al. An European myeloma network recommendation on tools for diagnosis and monitoring of multiple myeloma: what to use and when. Haematolgica. (2018) 103:1772-84.

65. Rajkumar SV, Dimopoulos MA, Palumbo A, Blade J, Merlini G, Mateos MV, et al. International myeloma working group updated criteria for the diagnosis of multiple myeloma. Lancet Oncol. (2014) 15:e538-48.

66. Greipp PR, Miguel JS, Dune BGM, Crowley JJ, Barlogie B, Bladé J, et al. International staging system for multiple myeloma. J Clin Oncol. (2005) 23:3412-20.

67. Palumbo A, Avet-Loiseau H, Oliva S, Lokhorst HM, Goldschmidt H, Rosinol $\mathrm{L}$, et al. Revised international staging system for multiple myeloma: A report from international myeloma working group. J Clin Oncol. (2015) 33:2863-9. doi: 10.1200/JCO.2015.61.2267

68. Dhodapkar MV, Borrello I, Cohen AD, Stadtmauer EA. Hematologic malignancies: plasma cell disorders. Am Soc Clin Oncol Educ Book . (2017) 37:561-8.

69. Armitage JO, Gascoyne RD, Lunning MA, Cavalli F. Non-hodgkin lymphoma. Lancet (London, England). (2017) 390:298-310.

70. Smith A, Howell D, Patmore R, Jack A, Roman E. Incidence of haematological malignancy by sub-type: a report from the haematological malignancy research network. Br J Cancer. (2011) 105:1684-92. doi: 10.1038/bjc.2011. 450

71. Ninkovic S, Lambert J. Non-Hodgkin lymphoma. Medicine (Baltimore). (2017) 45:297-304.

72. Solimando AG, Ribatti D, Vacca A, Einsele H. Targeting B-cell non Hodgkin lymphoma: new and old tricks. Leuk Res. (2016) 42:93-104. doi: 10.1016/j. leukres.2015.11.001

73. Cheson BD, Fisher RI, Barrington SF, Cavalli F, Schwartz LH, Zucca E, et al. Recommendations for initial evaluation, staging, and response assessment of Hodgkin and non-Hodgkin lymphoma: the Lugano classification. J Clin Oncol. (2014) 32:3059-68.

74. Bottcher S, Ritgen M, Fischer K, Stilgenbauer S, Busch RM, Fingerle-Rowson $\mathrm{G}$, et al. Minimal residual disease quantification is an independent predictor of progression-free and overall survival in chronic lymphocytic leukemia: a multivariate analysis from the randomized GCLLSG CLL8 trial. J Clin Oncol. (2012) 30:980-8. doi: 10.1200/JCO.2011.36.9348

75. Ahamadi-Fesharaki R, Fateh A, Vaziri F, Solgi G, Siadat SD, Mahboudi F, et al. Single-chain variable fragment-based bispecific antibodies: hitting two targets with one sophisticated arrow. Mol Ther Oncolytics. (2019) 14:38-56. doi: 10.1016/j.omto.2019.02.004

76. Hammer O. CD19 as an attractive target for antibody-based therapy. MAbs. (2012) 4:571-7. doi: 10.4161/mabs.21338

77. Wang K, Wei G, Liu D. CD19: a biomarker for B cell development, lymphoma diagnosis and therapy. Exp Hematol Oncol. (2012) 1:36. doi: 10. 1186/2162-3619-1-36

78. Baeuerle PA, Kufer P, Bargou R. BiTE: teaching antibodies to engage T-cells for cancer therapy. Curr Opin Mol Ther. (2009) 11:22-30.

79. Nagorsen D, Kufer P, Baeuerle PA, Bargou R. Blinatumomab: a historical perspective. Pharmacol Ther. (2012) 136:334-42. doi: 10.1016/j.pharmthera. 2012.07.013

80. Topp MS, Gokbuget N, Zugmaier G, Klappers P, Stelljes M, Neumann S, et al. Phase II trial of the anti-CD19 bispecific T cell-engager blinatumomab shows hematologic and molecular remissions in patients with relapsed or refractory B-precursor acute lymphoblastic leukemia. J Clin Oncol. (2014) 32:4134-40. doi: 10.1200/JCO.2014.56.3247

81. Topp MS, Kufer P, Gokbuget N, Goebeler M, Klinger M, Neumann S, et al. Targeted therapy with the T-cell-engaging antibody blinatumomab of chemotherapy-refractory minimal residual disease in B-lineage acute lymphoblastic leukemia patients results in high response rate and prolonged leukemia-free survival. J Clin Oncol. (2011) 29:2493-8. doi: 10.1200/JCO. 2010.32.7270

82. Topp MS, Gokbuget N, Zugmaier G, Degenhard E, Goebeler M-E, Klinger M, et al. Long-term follow-up of hematologic relapse-free survival in a phase 2 study of blinatumomab in patients with MRD in B-lineage ALL. Blood. (2012) 120:5185-7. doi: 10.1182/blood-2012-07-441030

83. Przepiorka D, Ko C-W, Deisseroth A, Yancey CL, Candau-Chacon R, Chiu H-J, et al. FDA Approval: Blinatumomab. Clin Cancer Res. (2015) 21:4035-9. doi: 10.1158/1078-0432.CCR-15-0612

84. Portell CA, Wenzell CM, Advani AS. Clinical and pharmacologic aspects of blinatumomab in the treatment of B-cell acute lymphoblastic leukemia. Clin Pharmacol. (2013) 5(Suppl. 1):5-11. doi: 10.2147/CPAA.S42689

85. Liu L, Lam C-YK, Long V, Widjaja L, Yang Y, Li H, et al. MGD011, A CD19 $\mathrm{x}$ CD3 dual-affinity retargeting bi-specific molecule incorporating extended circulating half-life for the treatment of B-cell malignancies. Clin Cancer Res. (2017) 23:1506-18. doi: 10.1158/1078-0432.CCR-16-0666

86. Reusch U, Duell J, Ellwanger K, Herbrecht C, Knackmuss SH, Fucek I, et al. A tetravalent bispecific TandAb (CD19/CD3), AFM11, efficiently recruits T cells for the potent lysis of CD19(+) tumor cells. MAbs. (2015) 7:584-604. doi: 10.1080/19420862.2015.1029216

87. Buhmann R, Michael S, Juergen H, Horst L, Peschel C, Kolb H-J. Immunotherapy with FBTA05 (Bi20), a trifunctional bispecific anti-CD3 $\mathrm{x}$ anti-CD20 antibody and donor lymphocyte infusion (DLI) in relapsed or refractory B-cell lymphoma after allogeneic stem cell transplantation: study protocol of an investigator-driven. J Transl Med. (2013) 11:160. doi: 10.1186/ 1479-5876-11-160

88. Kieslich A, Ruf P, Lindhofer H, Buhmann R, Eggert A, Hundsdoerfer $\mathrm{P}$. Immunotherapy with the trifunctional anti-CD20 $\mathrm{x}$ anti-CD3 antibody FBTA05 in a patient with relapsed $\mathrm{t}(8 ; 14)$-positive posttransplant lymphoproliferative disease. Leuk Lymphoma. (2017) 58: 1989-92.

89. Schuster FR, Stanglmaier M, Woessmann W, Winkler B, Siepermann M, Meisel R, et al. Immunotherapy with the trifunctional anti-CD20 $\mathrm{x}$ antiCD3 antibody FBTA05 (Lymphomun) in paediatric high-risk patients with recurrent CD20-positive B cell malignancies. Br J Haematol. (2015) 169:90102. doi: $10.1111 /$ bjh. 13242

90. Smith EJ, Olson K, Haber LJ, Varghese B, Duramad P, Tustian AD, et al. A novel, native-format bispecific antibody triggering T-cell killing of B-cells is robustly active in mouse tumor models and cynomolgus monkeys. Sci Rep. (2015) 5:17943. doi: 10.1038/srep17943

91. Bannerji R, Brown JR, Advani RH, Arnason J, O’Brien SM, Allan $\mathrm{JN}$, et al. Phase 1 study of REGN1979, an anti-CD20 $\mathrm{x}$ anti-CD3 bispecific monoclonal antibody, in patients with CD20+ B-cell malignancies previously treated with CD20-directed antibody therapy. Blood. (2016) 128:621.

92. Schuster SJ, Bartlett NL, Assouline S, Yoon S-S, Bosch F, Sehn LH, et al. Mosunetuzumab induces complete remissions in poor prognosis NonHodgkin lymphoma patients, including those who are resistant to or relapsing after chimeric antigen receptor T-cell (CAR-T) therapies, and is active in treatment through multiple lines. Blood. (2019) 134(Suppl. 1):6.

93. Bacac M, Umaña P, Herter S, Colombetti S, Sam J, Le Clech M, et al. CD20 Tcb (RG6026), a Novel "2:1" T Cell Bispecific Antibody for the Treatment of B Cell Malignancies. Blood. (2016) 128:1836.

94. Reusch U, Burkhardt C, Fucek I, Le Gall F, Le Gall M, Hoffmann K, et al. A novel tetravalent bispecific TandAb (CD30/CD16A) efficiently recruits NK cells for the lysis of CD30+ tumor cells. MAbs. (2014) 6:728-39. doi: $10.4161 /$ mabs. 28591

95. Bacac M, Colombetti S, Herter S, Sam J, Perro M, Chen S, et al. CD20TCB with obinutuzumab pretreatment as next-generation treatment of hematologic malignancies. Clin Cancer Res. (2018) 24:4785-97. doi: 10.1158/ 1078-0432.CCR-18-0455

96. Deaglio S, Aydin S, Vaisitti T, Bergui L, Malavasi F. CD38 at the junction between prognostic marker and therapeutic target. Trends Mol Med. (2008) 14:210-8. doi: 10.1016/j.molmed.2008.02.005

97. Zuch de Zafra CL, Fajardo F, Zhong W, Bernett MJ, Muchhal US, Moore GL, et al. Targeting multiple myeloma with AMG 424, a novel Anti-CD38/CD3 bispecific t-cell-recruiting antibody optimized for cytotoxicity and cytokine release. Clin Cancer Res. (2019) 25:3921-33. doi: 10.1158/1078-0432.CCR18-2752

98. Chu SY, Miranda Y, Phung S, Chen H, Rashid R, Endo NA, et al. Immunotherapy with long-lived Anti-CD38 $\times$ Anti-CD3 bispecific antibodies stimulates potent T cell-mediated killing of human AML cell lines 
and of CD38+ cells in monkeys: a potential therapy for acute myelogenous leukemia. Blood. (2014) 124:4727.

99. Tai Y-T, Anderson KC. Targeting B-cell maturation antigen in multiple myeloma. Immunotherapy. (2015) 7:1187-99. doi: 10.2217/imt.15.77

100. Carpenter RO, Evbuomwan MO, Pittaluga S, Rose JJ, Raffeld M, Yang S, et al. $\mathrm{B}$-cell maturation antigen is a promising target for adoptive T-cell therapy of multiple myeloma. Clin Cancer Res. (2013) 19:2048-60. doi: 10.1158/10780432.CCR-12-2422

101. O'Connor BP, Raman VS, Erickson LD, Cook WJ, Weaver LK, Ahonen C, et al. BCMA is essential for the survival of long-lived bone marrow plasma cells. J Exp Med. (2004) 199:91-8.

102. Hipp S, Tai Y-T, Blanset D, Deegen P, Wahl J, Thomas O, et al. A novel BCMA/CD3 bispecific T-cell engager for the treatment of multiple myeloma induces selective lysis in vitro and in vivo. Leukemia. (2017) 31:1743-51. doi: 10.1038/leu.2016.388

103. Seckinger A, Delgado JA, Moser S, Moreno L, Neuber B, Grab A, et al. Target expression, generation, preclinical activity, and pharmacokinetics of the BCMA-T cell bispecific antibody EM801 for multiple myeloma treatment. Cancer Cell. (2017) 31:396-410. doi: 10.1016/j.ccell.2017.02.002

104. Costa LJ, Wong SW, Bermúdez A, de la Rubia J, Mateos M-V, Ocio EM, et al. First clinical study of the B-cell maturation antigen (BCMA) $2+1 \mathrm{~T}$ cell engager (TCE) CC-93269 in patients (Pts) with relapsed/refractory multiple myeloma (RRMM): interim results of a phase 1 multicenter trial. Blood. (2019) 134(Suppl. 1):143.

105. Panowski SH, Kuo TC, Zhang Y, Chen A, Geng T, Aschenbrenner L, et al. Preclinical efficacy and safety comparison of $\mathrm{CD} 3$ bispecific and ADC modalities targeting BCMA for the treatment of multiple myeloma. $\mathrm{Mol}$ Cancer Ther. (2019) 18:2008-20. doi: 10.1158/1535-7163.MCT-19-0007

106. Lesokhin AM, Raje N, Gasparetto CJ, Walker J, Krupka HI, Joh T, et al. A Phase I, open-label study to evaluate the safety, pharmacokinetic, pharmacodynamic, and clinical activity of PF-06863135, a B-cell maturation antigen/CD3 bispecific antibody, in patients with relapsed/refractory advanced multiple myeloma. Blood. (2018) 132(Suppl. 1):3229.

107. Polson AG, Zheng B, Elkins K, Chang W, Du C, Dowd P, et al. Expression pattern of the human FCRH/IRTA receptors in normal tissue and in B-chronic lymphocytic leukemia. Int Immunol. (2006) 18:1363-73.

108. Ise T, Nagata S, Kreitman RJ, Wilson WH, Wayne AS, Stetler-Stevenson $\mathrm{M}$, et al. Elevation of soluble CD307 (IRTA2/FcRH5) protein in the blood and expression on malignant cells of patients with multiple myeloma, chronic lymphocytic leukemia, and mantle cell lymphoma. Leukemia. (2007) 21:169-74.

109. Kodama T, Kochi Y, Nakai W, Mizuno H, Baba T, Habu K, et al. AntiGPRC5D/CD3 bispecific T-cell-redirecting antibody for the treatment of multiple myeloma. Mol Cancer Ther. (2019) 18:1555-64. doi: 10.1158/15357163.MCT-18- 1216

110. Atamaniuk J, Gleiss A, Porpaczy E, Kainz B, Grunt TW, Raderer M, et al. Overexpression of $\mathrm{G}$ protein-coupled receptor $5 \mathrm{D}$ in the bone marrow is associated with poor prognosis in patients with multiple myeloma. Eur J Clin Invest. (2012) 42:953-60. doi: 10.1111/j.1365-2362.2012.02679.x

111. Lee DW, Gardner R, Porter DL, Louis CU, Ahmed N, Jensen M, et al. Current concepts in the diagnosis and management of cytokine release syndrome. Blood. (2014) 124:188-95. doi: 10.1182/blood-2014-05-552729

112. Li J, Piskol R, Ybarra R, Chen Y-JJ, Li J, Slaga D, et al. CD3 bispecific antibodyinduced cytokine release is dispensable for cytotoxic T cell activity. Sci Transl Med. (2019) 11:eaax8861. doi: 10.1126/scitranslmed.aax8861

113. Tanaka T, Narazaki M, Kishimoto T. Immunotherapeutic implications of IL-6 blockade for cytokine storm. Immunotherapy. (2016) 8:959-70. doi: 10.2217/imt-2016-0020

114. Shimabukuro-Vornhagen A, Godel P, Subklewe M, Stemmler HJ, Schlosser HA, Schlaak M, et al. Cytokine release syndrome. J Immunother Cancer. (2018) 6:56. doi: 10.1186/s40425-018-0343-9

115. Barrett DM, Teachey DT, Grupp SA. Toxicity management for patients receiving novel T-cell engaging therapies. Curr Opin Pediatr. (2014) 26:43-9. doi: 10.1097/MOP.0000000000000043

116. Faroudi M, Utzny C, Salio M, Cerundolo V, Guiraud M, Muller S, et al. Lytic versus stimulatory synapse in cytotoxic T lymphocyte/target cell interaction: manifestation of a dual activation threshold. Proc Natl Acad Sci USA. (2003) 100:14145-50.
117. Sibener LV, Fernandes RA, Kolawole EM, Carbone CB, Liu F, McAffee D, et al. Isolation of a structural mechanism for uncoupling $\mathrm{T}$ cell receptor signaling from peptide-MHC binding. Cell. (2018) 174:672-87.e27. doi: 10.1016/j.cell. 2018.06.017

118. Trinklein ND, Pham D, Schellenberger U, Buelow B, Boudreau A, Choudhry $\mathrm{P}$, et al. Efficient tumor killing and minimal cytokine release with novel T-cell agonist bispecific antibodies. MAbs. (2019) 11:639-52. doi: 10.1080/ 19420862.2019.1574521

119. Magge RS, DeAngelis LM. The double-edged sword: neurotoxicity of chemotherapy. Blood Rev. (2015) 29:93-100. doi: 10.1016/j.blre.2014.09.012

120. Goebeler M-E, Knop S, Viardot A, Kufer P, Topp MS, Einsele H, et al. Bispecific T-cell engager (BiTE) antibody construct blinatumomab for the treatment of patients with relapsed/refractory non-hodgkin lymphoma: final results from a phase I study. J Clin Oncol. (2016) 34:1104-11. doi: 10.1200/ JCO.2014.59.1586

121. Brandl C, Haas C, d'Argouges S, Fisch T, Kufer P, Brischwein K, et al. The effect of dexamethasone on polyclonal $\mathrm{T}$ cell activation and redirected target cell lysis as induced by a CD19/CD3-bispecific single-chain antibody construct. Cancer Immunol Immunother. (2007) 56:1551-63.

122. Woo S-R, Turnis ME, Goldberg MV, Bankoti J, Selby M, Nirschl CJ, et al. Immune inhibitory molecules LAG-3 and PD-1 synergistically regulate T-cell function to promote tumoral immune escape. Cancer Res. (2012) 72:917-27. doi: 10.1158/0008-5472.CAN-11-1620

123. Johnston RJ, Comps-Agrar L, Hackney J, Yu X, Huseni M, Yang Y, et al. The immunoreceptor TIGIT regulates antitumor and antiviral CD8(+) T cell effector function. Cancer Cell. (2014) 26:923-37. doi: 10.1016/j.ccell.2014.10. 018

124. Day CL, Kaufmann DE, Kiepiela P, Brown JA, Moodley ES, Reddy S, et al. PD-1 expression on HIV-specific T cells is associated with T-cell exhaustion and disease progression. Nature. (2006) 443:350-4.

125. Ruella M, Maus MV. Catch me if you can: leukemia escape after CD19directed T cell immunotherapies. Comput Struct Biotechnol J. (2016) 14:35762.

126. Arndt C, Feldmann A, von Bonin M, Cartellieri M, Ewen E-M, Koristka S, et al. Costimulation improves the killing capability of $\mathrm{T}$ cells redirected to tumor cells expressing low levels of CD33: description of a novel modular targeting system. Leukemia. (2014) 28:59-69. doi: 10.1038/leu.2013.243

127. Liu R, Jiang W, Yang $M$, Guo H, Zhang Y, Wang J, et al. Efficient inhibition of human B-cell lymphoma in SCID mice by synergistic antitumor effect of human 4-1BB ligand/anti-CD20 fusion proteins and antiCD3/anti-CD20 diabodies. J Immunother. (2010) 33:500-9. doi: 10.1097/CJI. 0b013e3181d75c20

128. Schmohl JU, Felices M, Oh F, Lenvik AJ, Lebeau AM, Panyam J, et al. Engineering of Anti-CD133 trispecific molecule capable of inducing NK expansion and driving antibody-dependent cell-mediated cytotoxicity. Cancer Res Treat. (2017) 49:1140-52. doi: 10.4143/crt. 2016.491

129. Khan S, Gerber DE. Autoimmunity, checkpoint inhibitor therapy and immune-related adverse events: a review. Semin Cancer Biol. (2019) S1044579X(19)30019-7. doi: 10.1016/j.semcancer.2019.06.012

130. Braig F, Brandt A, Goebeler M, Tony H-P, Kurze A-K, Nollau P, et al. Resistance to anti-CD19/CD3 BiTE in acute lymphoblastic leukemia may be mediated by disrupted CD19 membrane trafficking. Blood. (2017) 129:100-4. doi: 10.1182/blood-2016-05-718395

131. Sotillo E, Barrett DM, Black KL, Bagashev A, Oldridge D, Wu G, et al. Convergence of acquired mutations and alternative splicing of CD19 enables resistance to CART-19 immunotherapy. Cancer Discov. (2015) 5:1282-95. doi: 10.1158/2159-8290.CD-15-1020

132. Bachanova V, Frankel AE, Cao Q, Lewis D, Grzywacz B, Verneris MR, et al. Phase I study of a bispecific ligand-directed toxin targeting CD22 and CD19 (DT2219) for refractory B-cell malignancies. Clin Cancer Res. (2015) 21:1267-72. doi: 10.1158/1078-0432.CCR-14-2877

133. Koristka S, Cartellieri M, Theil A, Feldmann A, Arndt C, Stamova S, et al. Retargeting of human regulatory $\mathrm{T}$ cells by single-chain bispecific antibodies. J Immunol. (2012) 188:1551-8. doi: 10.4049/jimmunol.1101760

134. Pardoll DM. The blockade of immune checkpoints in cancer immunotherapy. Nat Rev Cancer . (2012) 12:252-64. doi: 10.1038/nrc 3239 
135. Krupka C, Kufer P, Kischel R, Zugmaier G, Lichtenegger FS, Kohnke T, et al. Blockade of the PD-1/PD-L1 axis augments lysis of AML cells by the CD33/CD3 BiTE antibody construct AMG 330: reversing a T-cell-induced immune escape mechanism. Leukemia. (2016) 30:484-91. doi: 10.1038/leu. 2015.214

136. Knaus HA, Kanakry CG, Luznik L, Gojo I. Immunomodulatory drugs: immune checkpoint agents in acute leukemia. Curr Drug Targets. (2017) 18:315-31. doi: 10.2174/1389450116666150518095346

137. Naidoo J, Wang X, Woo KM, Iyriboz T, Halpenny D, Cunningham J, et al. Pneumonitis in patients treated with anti-programmed death1/programmed death ligand 1 therapy. J Clin Oncol. (2017) 35:709-17. doi: 10.1200/JCO.2016.68.2005

138. Weber JS, Hodi FS, Wolchok JD, Topalian SL, Schadendorf D, Larkin J, et al. Safety profile of nivolumab monotherapy: a pooled analysis of patients with advanced melanoma. J Clin Oncol. (2017) 35:785-92. doi: 10.1200/JCO.2015. 66.1389

139. Tajiri K, Aonuma K, Sekine I. Immune checkpoint inhibitor-related myocarditis. Jpn J Clin Oncol. (2018) 48:7-12. doi: 10.1093/jjco/hyx154

140. Feucht J, Kayser S, Gorodezki D, Hamieh M, Doring M, Blaeschke F, et al. T-cell responses against CD19+ pediatric acute lymphoblastic leukemia mediated by bispecific T-cell engager (BiTE) are regulated contrarily by PDL1 and CD80/CD86 on leukemic blasts. Oncotarget. (2016) 7:76902-19. doi: 10.18632/oncotarget.12357

141. Correnti CE, Laszlo GS, de van der Schueren WJ, Godwin CD, Bandaranayake A, Busch MA, et al. Simultaneous multiple interaction T-cell engaging (SMITE) bispecific antibodies overcome bispecific T-cell engager (BiTE) resistance via CD28 co-stimulation. Leukemia. (2018) 32:1239-43.

142. La Motte-Mohs R, Shah K, Smith DH, Gorlatov S, Ciccarone V, Tamura J, et al. Abstract 3217: MGD013, a bispecific PD-1 x LAG-3 dual-affinity Re-targeting (DART§) protein with T-cell Immunomodulatory activity for cancer treatment. Am Assoc Cancer Res Annu Meet. (2016) 76(14 Suppl.): 3217.

143. Dovedi SJ, Mazor Y, Elder M, Hasani S, Wang B, Mosely S, et al. Abstract 2776: MEDI5752: a novel bispecific antibody that preferentially targets CTLA-4 on PD-1 expressing T-cells. Cancer Res. (2018) 78(13 Suppl.):2776.

144. Ye Q, Song D-G, Poussin M, Yamamoto T, Best A, Li C, et al. CD137 accurately identifies and enriches for naturally occurring tumor-reactive $\mathrm{T}$ cells in tumor. Clin Cancer Res. (2014) 20:44-55. doi: 10.1158/1078-0432. CCR-13-0945

145. Houot R, Kohrt H, Levy R. Boosting antibody-dependant cellular cytotoxicity against tumor cells with a CD137 stimulatory antibody. Oncoimmunology. (2012) 1:957-8.

146. Qi X, Li F, Wu Y, Cheng C, Han P, Wang J, et al. Optimization of 4-1BB antibody for cancer immunotherapy by balancing agonistic strength with FcgammaR affinity. Nat Commun. (2019) 10:2141. doi: 10.1038/s41467-01910088-1

147. Tolcher AW, Sznol M, Hu-Lieskovan S, Papadopoulos KP, Patnaik A, Rasco DW, et al. Phase Ib study of utomilumab (PF-05082566), a 4-1BB/CD137 agonist, in combination with pembrolizumab (MK-3475) in patients with advanced solid tumors. Clin Cancer Res. (2017) 23:5349-57. doi: 10.1158/ 1078-0432.CCR-17-1243

148. Segal NH, Logan TF, Hodi FS, McDermott D, Melero I, Hamid O, et al. Results from an integrated safety analysis of urelumab, an agonist AntiCD137 monoclonal antibody. Clin Cancer Res. (2017) 23:1929-36. doi: 10. 1158/1078-0432.CCR-16-1272

149. Eskiocak U, Guzman W, Wolf B, Cummings C, Milling L, Wu H-J, et al. Differentiated agonistic antibody targeting CD137 eradicates large tumors without hepatotoxicity. JCI Insight. (2020) 5:e133647. doi: 10.1172/jci.insight. 133647

150. Mikkelsen K, Harwood SL, Compte M, Merino N, Molgaard K, Lykkemark $S$, et al. Carcinoembryonic antigen (CEA)-specific 4-1BB-costimulation induced by CEA-targeted 4-1BB-agonistic trimerbodies. Front Immunol. (2019) 10:1791. doi: 10.3389/fimmu.2019.01791

151. Hinner MJ, Aiba RSB, Jaquin TJ, Berger S, Durr MC, Schlosser C, et al. Tumor-localized costimulatory T-cell engagement by the 4-1BB/HER2 bispecific antibody-anticalin fusion PRS-343. Clin Cancer Res. (2019) 25:5878-89. doi: 10.1158/1078-0432.CCR-18-3654
152. Van Blarcom T, Lindquist K, Melton Z, Cheung WL, Wagstrom C, McDonough D, et al. Productive common light chain libraries yield diverse panels of high affinity bispecific antibodies. MAbs. (2018) 10:256-68. doi: 10.1080/19420862.2017.1406570

153. Claus C, Ferrara C, Xu W, Sam J, Lang S, Uhlenbrock F, et al. Tumor-targeted 4-1BB agonists for combination with $\mathrm{T}$ cell bispecific antibodies as off-theshelf therapy. Sci Transl Med. (2019) 11:eaav5989. doi: 10.1126/scitranslmed. aav5989

154. Jaiswal S, Jamieson CHM, Pang WW, Park CY, Chao MP, Majeti R, et al. CD47 is upregulated on circulating hematopoietic stem cells and leukemia cells to avoid phagocytosis. Cell. (2009) 138:271-85. doi: 10.1016/j.cell.2009.05.046

155. Liu X, Pu Y, Cron K, Deng L, Kline J, Frazier WA, et al. CD47 blockade triggers $\mathrm{T}$ cell-mediated destruction of immunogenic tumors. Nat Med. (2015) 21:1209-15. doi: 10.1038/nm.3931

156. Subramanian S, Parthasarathy R, Sen S, Boder ET, Discher DE. Species- and cell type-specific interactions between CD47 and human SIRPalpha. Blood. (2006) 107:2548-56.

157. Dheilly E, Moine V, Broyer L, Salgado-Pires S, Johnson Z, Papaioannou A, et al. Selective blockade of the ubiquitous checkpoint receptor CD47 is enabled by dual-targeting bispecific antibodies. Mol Ther. (2017) 25:523-33. doi: 10.1016/j.ymthe.2016.11.006

158. van Bommel PE, He Y, Schepel I, Hendriks MAJM, Wiersma VR, van Ginkel RJ, et al. CD20-selective inhibition of CD47-SIRPalpha "don't eat me" signaling with a bispecific antibody-derivative enhances the anticancer activity of daratumumab, alemtuzumab and obinutuzumab. Oncoimmunology. (2018) 7:e1386361.

159. Kyle RA, Remstein ED, Therneau TM, Dispenzieri A, Kurtin PJ, Hodnefield JM, et al. Clinical course and prognosis of smoldering (asymptomatic) multiple myeloma. N Engl J Med. (2007) 356:2582-90.

160. Baker D, Marta M, Pryce G, Giovannoni G, Schmierer K. Memory B cells are major targets for effective immunotherapy in relapsing multiple sclerosis. EBioMedicine. (2017) 16:41-50. doi: 10.1016/j.ebiom.2017.01.042

161. Sen M, Wankowski DM, Garlie NK, Siebenlist RE, Van Epps D, LeFever AV, et al. Use of anti-CD3 $\mathrm{x}$ anti-HER2/neu bispecific antibody for redirecting cytotoxicity of activated T cells toward HER2/neu+ tumors. J Hematother Stem Cell Res. (2001) 10:247-60.

162. Schaefer W, Regula JT, Bahner M, Schanzer J, Croasdale R, Durr H, et al. Immunoglobulin domain crossover as a generic approach for the production of bispecific IgG antibodies. Proc Natl Acad Sci USA. (2011) 108:11187-92. doi: 10.1073/pnas.1019002108

163. Klein C, Schaefer W, Regula JT, Dumontet C, Brinkmann U, Bacac M, et al. Engineering therapeutic bispecific antibodies using CrossMab technology. Methods. (2019) 154:21-31. doi: 10.1016/j.ymeth.2018.11.008

164. Tustian AD, Endicott C, Adams B, Mattila J, Bak H. Development of purification processes for fully human bispecific antibodies based upon modification of protein a binding avidity. MAbs. (2016) 8:828-38. doi: 10 . 1080/19420862.2016.1160192

165. Davis JH, Aperlo C, Li Y, Kurosawa E, Lan Y, Lo K-M, et al. SEEDbodies: fusion proteins based on strand-exchange engineered domain (SEED) $\mathrm{CH} 3$ heterodimers in an $\mathrm{Fc}$ analogue platform for asymmetric binders or immunofusions and bispecific antibodies. Protein Eng Des Sel. (2010) 23:195202. doi: 10.1093/protein/gzp094

166. Geuijen CAW, De Nardis C, Maussang D, Rovers E, Gallenne T, Hendriks LJA, et al. Unbiased combinatorial screening identifies a bispecific IgG1 that potently inhibits HER3 signaling via HER2-guided ligand blockade. Cancer Cell. (2018) 33:922-36.e10. doi: 10.1016/j.ccell.2018.04.003

167. De Nardis C, Lossl P, van den Biggelaar M, Madoori PK, Leloup N, Mertens K, et al. Recombinant expression of the full-length ectodomain of LDL receptorrelated protein 1 (LRP1) unravels $\mathrm{pH}$-dependent conformational changes and the stoichiometry of binding with receptor-associated protein (RAP). J Biol Chem. (2017) 292:912-24. doi: 10.1074/jbc.M116.758862

168. Moore GL, Bernett MJ, Rashid R, Pong EW, Nguyen D-HT, Jacinto J, et al. A robust heterodimeric Fc platform engineered for efficient development of bispecific antibodies of multiple formats. Methods. (2019) 154:38-50. doi: 10.1016/j.ymeth.2018.10.006

169. Labrijn AF, Meesters JI, de Goeij BECG, van den Bremer ETJ, Neijssen J, van Kampen MD, et al. Efficient generation of stable bispecific IgG1 by 
controlled Fab-arm exchange. Proc Natl Acad Sci USA. (2013) 110:5145-50. doi: 10.1073/pnas.1220145110

170. Stanglmaier M, Faltin M, Ruf P, Bodenhausen A, Schroder P, Lindhofer H. Bi20 (fBTA05), a novel trifunctional bispecific antibody (anti-CD20 $\mathrm{x}$ antiCD3), mediates efficient killing of B-cell lymphoma cells even with very low CD20 expression levels. Int J Cancer. (2008) 123:1181-9. doi: 10.1002/ijc. 23626

171. Loffler A, Kufer P, Lutterbuse R, Zettl F, Daniel PT, Schwenkenbecher $\mathrm{JM}$, et al. A recombinant bispecific single-chain antibody, CD19 x CD3, induces rapid and high lymphoma-directed cytotoxicity by unstimulated $\mathrm{T}$ lymphocytes. Blood. (2000) 95:2098-103.

172. Bruenke J, Barbin K, Kunert S, Lang P, Pfeiffer M, Stieglmaier K, et al. Effective lysis of lymphoma cells with a stabilised bispecific single-chain Fv antibody against CD19 and FcgammaRIII (CD16). Br J Haematol. (2005) 130:218-28.

173. Gleason MK, Verneris MR, Todhunter DA, Zhang B, McCullar V, Zhou SX. Bispecific and trispecific killer cell engagers directly activate human NK cells through CD16 signaling and induce cytotoxicity and cytokine production. Mol Cancer Ther. (2012) 11:2674-84. doi: 10.1158/1535-7163.MCT-12-0692

174. Brusselbach S, Kom T, Volkel T, Muller R, Kontermann RE. Enzyme recruitment and tumor cell killing in vitro by a secreted bispecific singlechain diabody. Tumor Target. (1999) 4:115-23.

175. Topp MS, Attal M, Langer C, Moreau P, Facon T, Düll J, et al. Phase 1 doseescalation study of BI 836909, an anti-BCMA bi-specific T-cell engager, in relapsed and/or refractory multiple myeloma (RRMM). J Clin Oncol. (2016) 34(15 Suppl.):TS8067.

176. Cho S-F, Lin L, Xing L, Wen K, Yu T, Wahl J, et al. AMG 701, a halflife extended anti-BCMA BiTE\$, potently induces T cell-redirected lysis of human multiple myeloma cells and can be combined with IMiDs to overcome the immunosuppressive bone marrow microenvironment. Clin Lymphoma Myeloma Leuk. (2019) 19:e54.

177. Girgis S, Shetty S, Jiao T, Amuzie C, Weinstock D, Watson RG, et al. Exploratory pharmacokinetic/pharmacodynamic and tolerability study of BCMAxCD3 in cynomolgus monkeys. Blood. (2016) 128:5668.

178. Dilillo DJ, Olson K, Mohrs K, Meagher TC, Bray K, Sineshchekova O, et al. REGN5458, a bispecific BCMAxCD3 T cell engaging antibody, demonstrates robust in vitro and in vivo anti-tumor efficacy in multiple myeloma models, comparable to that of BCMA CAR T Cells. Blood. (2018) 132(Suppl. 1):1944.

179. Richter JR, Wermke M, Kauh JS, Back J, Salhi Y, Reddy V, et al. Phase 1, multicenter, open-label study of single-agent bispecific antibody T-cell engager GBR 1342 in relapsed/refractory multiple myeloma. J Clin Oncol. (2018) 36(5 Suppl.):TS81.

180. Chu SY, Pong E, Hsing C, Phung S, Chan EW, Endo NA, et al. Immunotherapy with long-lived Anti-CD123 $\times$ Anti-CD3 bispecific antibodies stimulates potent $\mathrm{T}$ cell-mediated killing of human AML cell lines and of CD123+ cells in monkeys: a potential therapy for acute myelogenous leukemia. Blood. (2014) 124:2316.

181. Ravandi F, Bashey A, Foran JM, Stock W, Mawad R, Blum W, et al. Complete responses in relapsed/refractory acute myeloid leukemia (AML) patients on a weekly dosing schedule of XmAb14045, a CD123 x CD3 T cell-engaging bispecific antibody: initial results of a phase 1 study. Blood. (2018) 132(Suppl. 1):763.

182. Cui Y, Huang Z, Zhang X, Shen W, Chen H, Wen Z, et al. CD3-activating Bispecific antibody targeting CD19 on B cells in Mono- and Bi-valent format. Blood. (2018) 132(Suppl. 1):4169.

183. Popplewell L, Verhoef G, Kuruvilla J, Tuglus C, Kischel R, Stieglmaier J, et al. A first-in-human study of a half-life extended CD19-targeting BiTE in relapsed-refractory diffuse large B cell lymphoma, mantle cell lymphoma or follicular lymphoma. Hematol Oncol. (2019) 37(S2):566-7.

184. Pratz K, Gojo I, Gocke C, Matsui W, Huff C. Blinatumomab induced response of multiply refractory multiple myeloma in the context of secondary Pre-B cell acute lymphoblastic leukemia. Ann Hematol Oncol. (2017) 4:1174.
185. Hijazi Y, Klinger M, Kratzer A, Wu B, Baeuerle PA, Kufer P, et al. Pharmacokinetic and pharmacodynamic relationship of blinatumomab in patients with Non-Hodgkin lymphoma. Curr Clin Pharmacol. (2018) 13:5564. doi: 10.2174/1574884713666180518102514

186. Hiemstra I, Engelberts P, de Jong B, Schuurhuis D, Salcedo T, Verploegen $\mathrm{S}$, et al. Potent anti-tumor activity of duobody-CD3XCD20 in preclinical models in vitro and in vivo. HemaSphere. (2019) 3:594. doi: 10.1016/j.ebiom. 2019.102625

187. Ferl GZ, Reyes A, Sun LL, Cheu M, Oldendorp A, Ramanujan S, et al. A preclinical population pharmacokinetic model for Anti-CD20/CD3 T-celldependent bispecific antibodies. Clin Transl Sci. (2018) 11:296-304. doi: 10. $1111 /$ cts. 12535

188. Sun LL, Ellerman D, Mathieu M, Hristopoulos M, Chen X, Li Y, et al. AntiCD20/CD3 T cell-dependent bispecific antibody for the treatment of B cell malignancies. Sci Transl Med. (2015) 7:287ra70. doi: 10.1126/scitranslmed. aaa 4802

189. Chu SY, Lee S-H, Rashid R, Hsing C, Chan EW, Phung S, et al. Immunotherapy with long-lived Anti-CD20 $\times$ Anti-CD3 bispecific antibodies stimulates potent $\mathrm{T}$ cell-mediated killing of human $\mathrm{B}$ cell lines and of circulating and lymphoid B cells in monkeys: a potential therapy for B cell lymphomas and leukemias. Blood. (2014) 124: 31111.

190. Lum LG, Thakur A, Pray C, Kouttab N, Abedi M, Deol A, et al. Multiple infusions of CD20-targeted T cells and low-dose IL-2 after SCT for high-risk non-Hodgkin's lymphoma: a pilot study. Bone Marrow Transplant. (2014) 49:73-9. doi: 10.1038/bmt.2013.133

191. Lum LG, Thakur A, Liu Q, Deol A, Al-Kadhimi Z, Ayash L, et al. CD20targeted $\mathrm{T}$ cells after stem cell transplantation for high risk and refractory non-Hodgkin's lymphoma. Biol Blood Marrow Transplant. (2013) 19:925-33. doi: 10.1016/j.bbmt.2013.03.010

192. Wu J, Fu J, Zhang M, Liu D. AFM13: a first-in-class tetravalent bispecific antiCD30/CD16A antibody for NK cell-mediated immunotherapy. J Hematol Oncol. (2015) 8:96. doi: 10.1186/s13045-015-0188-3

193. Eckelman BP, Timmer JC, Hata C, Jones KS, Hussain A, Razai AS, et al. Multivalent and Multispecific 41BB-Binding Fusion Proteins. Patent No. US 2017/0198050 A1. San Diego, CA: Inhibrx. (2017).

194. Vallera DA, Chen H, Sicheneder AR, Panoskaltsis-Mortari A, Taras EP. Genetic alteration of a bispecific ligand-directed toxin targeting human CD19 and CD22 receptors resulting in improved efficacy against systemic B cell malignancy. Leuk Res. (2009) 33:1233-42. doi: 10.1016/j.leukres.2009. 02.006

195. Coward J, Ganju V, Behzadigohar R, Kwong K, Xu J, Van H, et al. Preliminary safety, efficacy, and pharmacokinetics (PK) results of KN046 (bispecific antiPD-L1/CTLA4) from a first-in-human study in subjects with advanced solid tumors. J Clin Oncol. (2019) 37(15 Supp.):2554.

196. Buatois V, Johnson Z, Salgado-Pires S, Papaioannou A, Hatterer E, Chauchet X, et al. Preclinical development of a bispecific antibody that safely and effectively targets CD19 and CD47 for the treatment of B-cell lymphoma and leukemia. Mol Cancer Ther. (2018) 17:1739-51. doi: 10.1158/1535-7163. MCT-17- 1095

Conflict of Interest: The authors declare that the research was conducted in the absence of any commercial or financial relationships that could be construed as a potential conflict of interest.

Copyright (c) 2020 Lejeune, Köse, Duray, Einsele, Beguin and Caers. This is an open-access article distributed under the terms of the Creative Commons Attribution License (CC BY). The use, distribution or reproduction in other forums is permitted, provided the original author(s) and the copyright owner(s) are credited and that the original publication in this journal is cited, in accordance with accepted academic practice. No use, distribution or reproduction is permitted which does not comply with these terms. 